\title{
In vivo proteomic mapping through GFP-directed proximity- dependent biotin labelling in zebrafish
}

\author{
Zherui Xiong ${ }^{1}$, Harriet P. Lo ${ }^{1}$, Kerrie-Ann McMahon ${ }^{1}$, Nick Martel ${ }^{1}$, Alun Jones ${ }^{1}$, Michelle M. Hill ${ }^{2}$, \\ Robert G. Parton ${ }^{1,3^{*}}$, Thomas E. Hall ${ }^{1^{*}}$ \\ ${ }^{1}$ Institute for Molecular Bioscience, The University of Queensland, Brisbane, QLD 4072, Australia. \\ ${ }^{2}$ QIMR Berghofer Medical Research Institute, Herston, QLD 4006, Australia \\ ${ }^{3}$ Centre for Microscopy and Microanalysis, The University of Queensland, Brisbane, QLD 4072, \\ Australia. \\ *Corresponding authors, equal contribution
}

\begin{abstract}
Protein interaction networks are crucial for complex cellular processes. However, the elucidation of protein interactions occurring within highly specialised cells and tissues is challenging. Here we describe the development, and application, of a new method for proximity-dependent biotin labelling in whole zebrafish. Using a conditionally stabilised GFP-binding nanobody to target a biotin ligase to GFP-labelled proteins of interest, we show tissue-specific proteomic profiling using existing GFP-tagged transgenic zebrafish lines. We demonstrate the applicability of this approach, termed BLITZ (Biotin Labelling In Tagged Zebrafish), in diverse cell types such as neurons and vascular endothelial cells. We applied this methodology to identify interactors of caveolar coat protein, cavins, in skeletal muscle. Using this system, we defined specific interaction networks within in vivo muscle cells for the closely related but functionally distinct Cavin4 and Cavin1 proteins.
\end{abstract}

\section{Introduction}

The understanding of the biological functions of a protein requires detailed knowledge of the molecules with which it interacts. However, robust elucidation of interacting proteins, including not only strong direct protein-protein interactions, but also weak, transient or indirect interactions is challenging. Proximity-dependent biotin labelling (BioID) using genetically engineered biotin ligases has emerged as a novel approach for studying protein-protein interactions and the subcellular proteome in living cells (Roux et al., 2012; Kim et al., 2016; Branon et al., 2018; Ramanathan et al., 2018). When fused to a protein of interest (POI) and expressed in cells, the promiscuous biotin ligases covalently attach biotin to all proteins within a $10 \mathrm{~nm}$ radius, which can be subsequently isolated by streptavidin purification and identified by mass spectrometry. Compared with traditional affinity purification with protein-specific antibodies or affinity purification tags, the BiolD method has the advantage of being able to capture weak and transient interactions. In addition, unlike conventional methods such as affinity purification, where stringent extraction conditions may disrupt protein-protein interactions, the BiolD method does not require proteins to be isolated in their native state. Therefore, harsh protein extraction and stringent wash conditions can be applied, which can improve solubilisation of membrane proteins and reduce false positives (Varnaite and MacNeill, 2016; Gingras et al., 2019).

The BiolD method has been widely applied in cell biology to study protein-protein interactions in cultured cells, providing valuable information for building protein interaction networks. However, the reductionist in vitro applications described to date, while powerful in their own right, lack the complexity and context to address phenomena that can only be modelled in vivo, for example the differentiation of specialised cell types such as those found in muscle, the nervous system and vasculature. The most recent generation of biotin ligases has been applied in vivo in invertebrate models; flies (Drosophila melanogaster) and worms (Caenorhabditis elegans) as well as plants (Arabidopsis and Nicotiana benthamiana) (Branon et al., 2018; Mair et al., 2019; Zhang et al., 2019). Until now however, the applicability of BiolD has been limited by the necessity to genetically tag each POI directly with a biotin ligase and generate transgenic organisms. Here we describe a more versatile approach to the in vivo application of BiolD in a vertebrate model organism, the zebrafish. Instead of directly fusing the biotin ligase to a POI, we developed a modular system for GFP-directed proteomic mapping by combining BiolD 
with a GFP-binding nanobody (Hamers-Casterman et al., 1993; Rothbauer et al., 2008; Tang et al., 2015; Ariotti et al., 2015). This system couples the power of the BioID system with the ability to use existing GFP-tagged transgenic zebrafish lines for proteomic mapping between different tissues and/or different proteins. We demonstrate the application of this system in screening for proteins associated with the caveolar cast proteins, Cavin1 and Cavin4, in differentiated skeletal muscle which has, to date, been difficult to achieve in culture. These analyses reveal proteins and pathways that are both overlapping and specific to Cavin1 and Cavin4.

\section{Results}

\section{Proximity biotinylation in live zebrafish embryos}

We first tested the ability of a number of biotin ligases to catalyse protein biotinylation in live zebrafish embryos. Initial attempts using BirA* or BiolD2 biotin ligases in vivo in zebrafish were unsuccessful and resulted in no detectable biotinylation in zebrafish embryos as assessed by streptavidin Western blotting (Supplementary Figure 1). In recent years, the new biolD biotin ligases, BASU, TurbolD and miniTurbo, have been developed and showed greatly improved catalytic efficiency and enhanced proximity labelling in cultured cells (Branon et al., 2018; Ramanathan et al., 2018). We therefore tested their ability to catalyse protein biotinylation in live zebrafish embryos. Untagged, cytoplasmically localised biotin ligases were transiently expressed in zebrafish embryos by RNA injection, and the level of protein biotinylation was assessed using streptavidin immunoblot analysis (experimental regimen illustrated in Figure 1A) (Ramanathan et al., 2018; Branon et al., 2018). The biotin ligase mRNA incorporated an EGFP tag for selection of transgene expressing embryos, and a Myc tag for detection of biotin ligase by Western blot. At $24 \mathrm{~h}$ post injection, the GFP-positive embryos were dechorionated before incubation in biotin-supplemented media for a further $18 \mathrm{~h}$ (Figure $1 \mathrm{~A}$ ). Total protein extracts from fish embryos were then subjected to SDS-PAGE and streptavidin immunoblotting (Figure 1B). TurbolD exhibited the strongest biotinylation of endogenous proteins among the three new biotin ligases with $500 \mu \mathrm{M}$ biotin. Therefore, we chose TurbolD for all subsequent experiments. Note the two prominent bands consistently detected around 70 and $135 \mathrm{kDa}$ in all samples likely represent endogenously biotinylated proteins (Housley et al., 2014; Ahmed et al., 2014).

To visualise TurbolD-catalysed biotinylation in situ, TurbolD-expressing embryos were stained with NeutrAvidinDyLight 550 after biotin incubation (Figure 1C). The mosaic expression of TurbolD-GFP in the muscle fibres, as well as expression in the yolk, corresponded with strong NeutrAvidin staining. The mRNA injections frequently gave rise to differing levels of expression between individual muscle cells within the same animal. Therefore, muscle fibres with little or no TurbolD-GFP expression served as an internal negative control.

Biotin concentration and incubation time are two crucial factors that affect biotin ligase efficiency in cultured cells (Roux et al., 2012; Kim et al., 2016; Branon et al., 2018; Ramanathan et al., 2018). To achieve the most effective experimental conditions for TurbolD application in zebrafish, we sought to optimise these parameters. From our initial experiments with BirA*, we knew that zebrafish embryos are able to tolerate a biotin concentration as high as $800 \mu \mathrm{M}$ with no obvious morphological abnormalities (Supplementary Figure 2A and B). To determine the optimal biotin concentration for TurbolD in zebrafish, TurbolD-expressing embryos were incubated in embryo medium containing biotin concentration ranging from 0 to $750 \mu \mathrm{M}$ for $18 \mathrm{~h}$, followed by lysis and streptavidin immunoblotting. Weak labelling could be seen with $50 \mu \mathrm{M}$ biotin, increasing through $250 \mu \mathrm{M}$, with the strongest labelling at concentration of 500 and $750 \mu \mathrm{M}$ (Figure 1D). Unlike its application in cultured cells and yeast (Branon et al., 2018), TurbolD did not produce detectable exogenous biotinylation without the addition of biotin (Figure 1D). This provides the opportunity for temporal resolution by addition of exogenous biotin at specific developmental stages. Unexpectedly, the anti-Myc immunoblot showed that a higher biotin concentration resulted in more TurbolD in the total protein extracts (Figure 1D). Concomitantly, the addition of exogenous biotin did not change the level of endogenous biotinylated proteins in the WT embryos (Figure1D).

In mammalian cell culture, a $10 \mathrm{~min}$ biotin incubation with TurbolD is sufficient to visualise biotinylated proteins by immunoblotting and to perform analysis of different organellar proteomes (Branon et al., 2018). However, we did not observe rapid biotinylation in zebrafish within the first $2 \mathrm{~h}$ of biotin incubation (Figure 1E). TurbolD-induced biotin labelling was only weakly detected after $4-6 \mathrm{~h}$ incubation and adequate biotinylation was only detected after overnight incubation (18 h). 
bioRxiv preprint doi: https://doi.org/10.1101/2020.11.05.370585; this version posted November 6, 2020. The copyright holder for this preprint (which was not certified by peer review) is the author/funder. All rights reserved. No reuse allowed without permission.

A

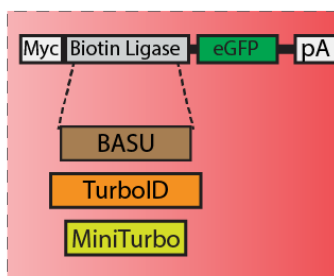

3 versions of biotin ligase

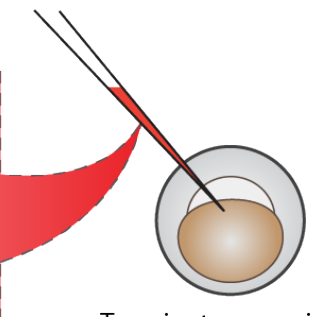

Transient expression by mRNA injection

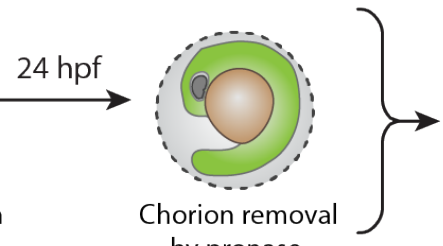

by pronase

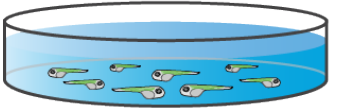

Incubate embryos in medium supplemented with biotin

Embryo solubilisation and Western Blot

Embryo permeabilisation and NeutrAvidin staining
B

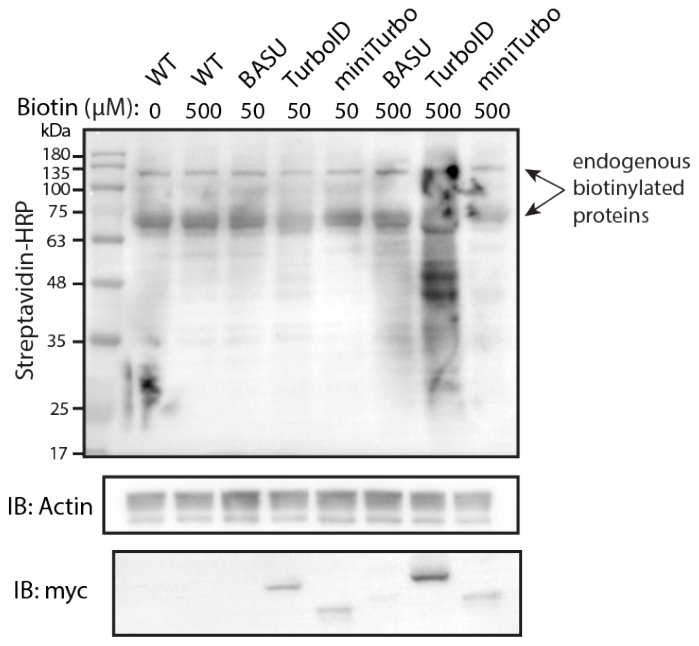

D

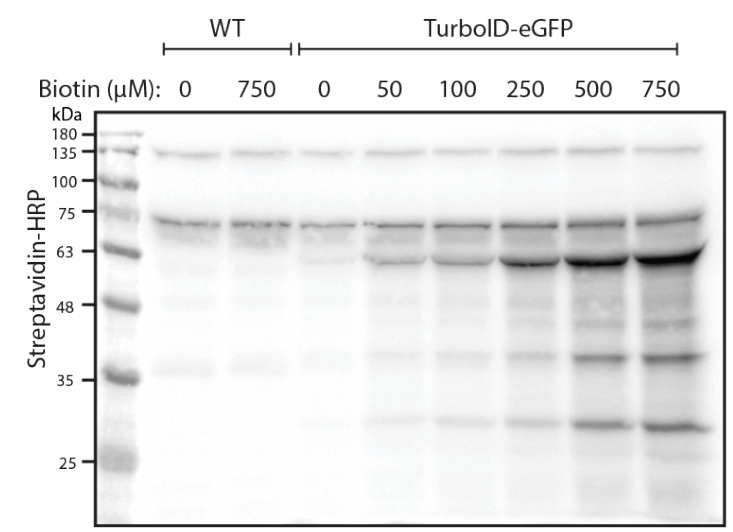

IB: Actin

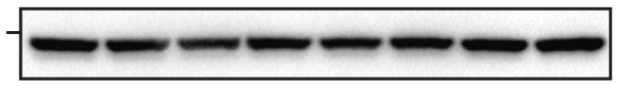

IB: Myc

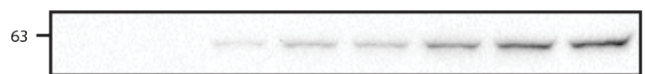

C

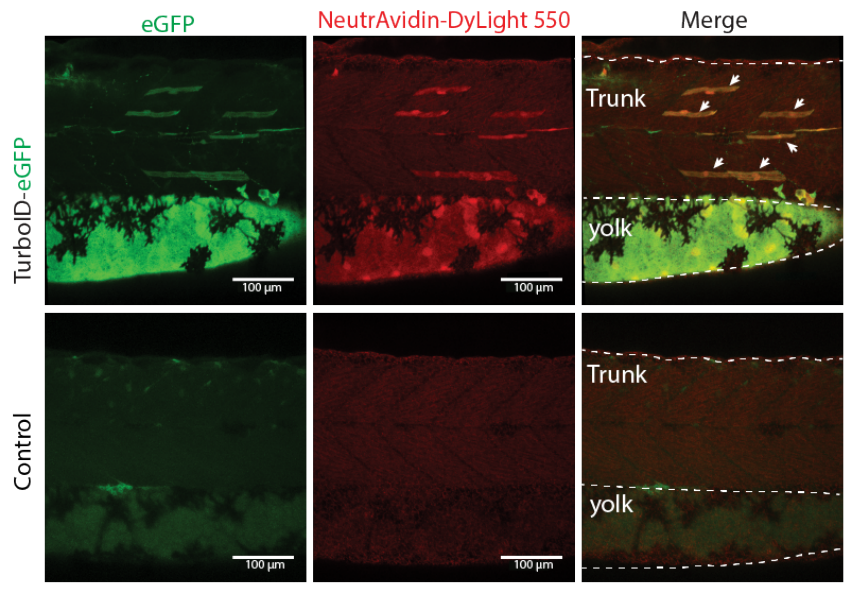

$\mathbf{E}$
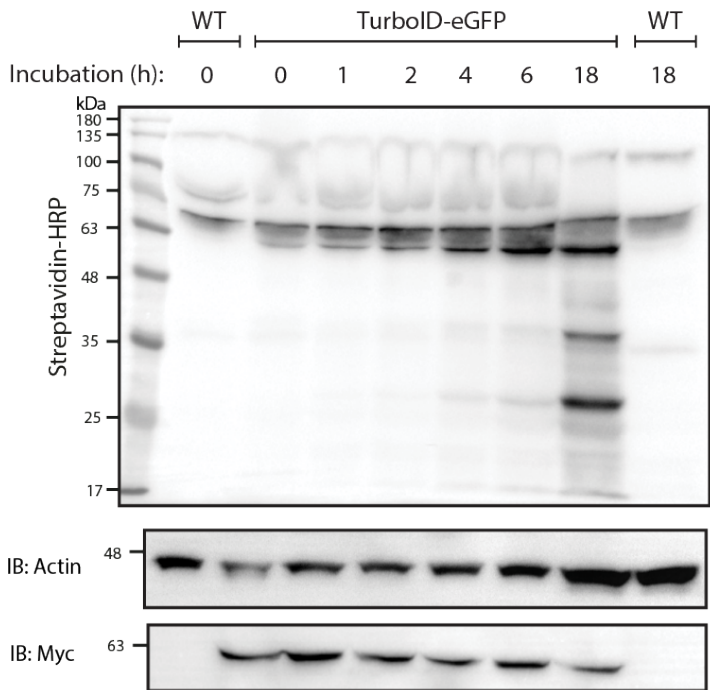

Figure 1 Testing and optimising biotin ligases: BASU, TurbolD and miniTurbo. (A) A schematic overview of the workflow. The BASU/TurboID/MiniTurbo was transiently expressed in zebrafish embryos by RNA injection. Chorion-removed fish embryos with green fluorescence were selected for incubation in biotin supplemented embryo media for $18 \mathrm{~h}$. After biotin incubation, embryos were analysed by Western blotting and immunofluorescence. (B) The streptavidin-HRP blot showing biotinylated proteins in 2 dpf zebrafish embryos expressing eGFP-tagged BASU, TurboID and miniTurbo. Fish embryos were incubated in biotin concentrations of 50 or $500 \mu M$ biotin for $18 \mathrm{~h}$ before embryo solubilisation and Western blot analysis. Actin immunoblot (IB:Actin) serves as a loading control; the anti-Myc immunoblot (IB:Myc) reflects the protein level of each biotin ligases; each sample is a pool of 30 embryos. (C) Representative images of NeutrAvidin staining of 
biotinylated proteins in 2 dpf zebrafish embryo transiently expressing TurbolD-eGFP. Fish muscle and yolk were outlined with dashed lines. White arrows indicate muscle fibres expressing TurbolD-eGFP. $n=6$. Scale bar denotes $100 \mu$ m (D and E) Dependency of TurbolD activity on biotin concentration and incubation time. Zebrafish embryos transiently expressing TurbolD-eGFP were incubated with embryo media containing 0 to $750 \mu \mathrm{M}$ biotin for $18 \mathrm{~h}(\boldsymbol{D})$ or incubated with $500 \mu \mathrm{M}$ biotin for 0 to $18 \mathrm{~h}(\mathrm{E})$ before protein extraction and immunoblot analysis with streptavidin-HRP, anti-Actin and anti-Myc antibodies; each sample is a pool of 30 embryos.

\section{In vivo proximity biotinylation targeted to a specific subcellular region or a protein of interest}

Next, we tested the spatial resolution of TurbolD-catalysed biotinylation in zebrafish when TurbolD was targeted to a specific subcellular region and to a POI. We tagged TurboID with a nuclear localisation signal (NLS), a plasma membrane localisation motif ( $\mathrm{CaaX}$ ), the transmembrane protein $\mathrm{CD} 44 \mathrm{~b}$ and the muscle T-tubule enriched membrane protein Cavin4b (Figure 2A). After biotin treatment, the TurbolD fusion proteins produced a biotinylation pattern corresponding to the appropriate subcellular location of targeting sequences/proteins in zebrafish embryos (Figure 2B). The spatial resolution of the biotin labelling was remarkable as even the T-tubule structure, which is difficult to resolve in fixed embryos, was clearly visible by NeutrAvidin staining in the embryos expressing Cavin4b-TurbolD. Furthermore, the biotinylated protein derived from each TurbolD construct gave rise to a unique barcode of protein bands on the streptavidin blot, indicative of proteins specific to each corresponding subcellular compartment (Figure $2 \mathrm{C}$ ). These results demonstrated that TurbolD was able to specifically label a selective subpopulation of endogenous proteins when targeted to a specific subcellular region or protein in zebrafish embryos. Moreover, the TurbolD-biotinylated proteins were recoverable from crude fish lysates by affinity purification with streptavidin-conjugated beads (Figure 2D), ready for downstream applications such as identification by mass spectrometry.

Overall, TurbolD showed robust biotin labelling with high spatial resolution in zebrafish embryos. These properties rendered it suitable for pursuing in vivo proteomic analyses.

\section{Conditionally stabilised GFP-binding protein (dGBP) is able to target GFP-tagged proteins in zebrafish}

Although we were able to achieve proximity-dependent biotin labelling in zebrafish embryos transiently expressing TurbolD by mRNA injection, this method requires the direct injection of a large number of newly fertilised embryos in order to obtain sufficient protein for subsequent mass spectrometry sequencing. It is a labour-intensive exercise when potentially analysing multiple POIs, and new genetic constructs must be generated for each POI. In addition, the protein expressed from mRNA injected at the one-cell stage becomes progressively depleted and is present only in trace amounts beyond three days post fertilisation. As such, this methodology is limited to early stage embryos. To circumvent these issues, we envisaged a modular system that would utilise the many existing stable zebrafish lines which express GFP-tagged proteins. Previously, we demonstrated that a GFP-binding peptide (GBP; a 14-kDa nanobody) is able to target a peroxidase (APEX2) to GFP-tagged POls in both cell culture and zebrafish systems (Ariotti et al., 2015), and can be used for ultrastructural localisation. Based on these findings, we reasoned that genetically fusing TurboID with GBP would target the TurbolD-GBP fusion protein to GFP-labelled POIs and/or subcellular compartments in zebrafish, enabling GFP-directed proximity biotinylation in vivo. Furthermore, generation of a stable zebrafish line expressing TurbolD-GBP would allow delivery of the transgene by a simple genetic cross, circumventing the need for microinjection and enabling continued expression beyond the embryonic stages.

As proof-of-principle, we fused a red fluorescent protein (mRuby2) with the GBP nanobody and transiently expressed it in a transgenic fish line already expressing Cavin1a-Clover. Clover is a GFP derivative recognised by GBP (Shaner et al., 2013), and Cavin1a is an ortholog of caveolae-associated protein 1 in zebrafish (Lo et al., 2015). When expressed at low levels, mRuby2-GBP showed clear colocalisation with Cavin1a-Clover at the plasma membrane in the mRuby2-positive muscle cells (Figure 3A). However, when mRuby-GBP was expressed at higher levels, red fluorescence was observed in the cytoplasm in addition to the plasma membrane, likely due to the saturation of binding between GBP and GFP. This observation raised concerns about the potential of non-specific labelling from unbound TurbolD-GBP under these conditions.

As a solution, we substituted the GBP with a conditionally stabilised GFP-nanobody (destabilised GBP or "dGBP") that is rapidly degraded unless the GFP-binding site is occupied (Tang et al., 2016; Ariotti et al., 2018). Using this approach, we observed tight association of mRuby2-dGBP and Cavin1a-Clover in all muscle cells regardless of expression level (Figure 3B). We reasoned that a system utilising the conditionally stabilised nanobody would be less likely to result in non-specific biotin labelling within target cells in vivo. Furthermore, use of the conditionally stabilised GBP gives potential for modularity, since tissue or cell type specific biotinylation will only occur in cells expressing both GFP-POI and TurbolD-dGBP fusion proteins. 
bioRxiv preprint doi: https://doi.org/10.1101/2020.11.05.370585; this version posted November 6, 2020. The copyright holder for this preprint (which was not certified by peer review) is the author/funder. All rights reserved. No reuse allowed without permission.

A

Constructs for testing spatial specificity of TurbolD in zebrafish
Target TurbolD to subcellular regions

B

TurbolD-eGFP

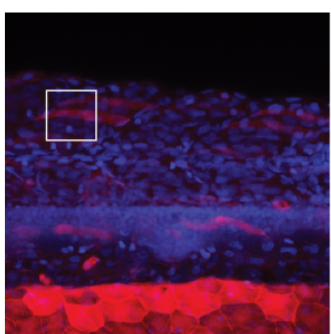

Control

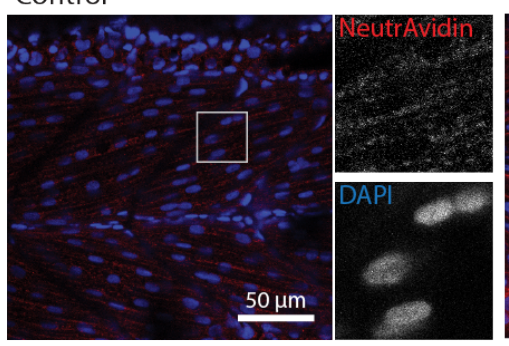

C

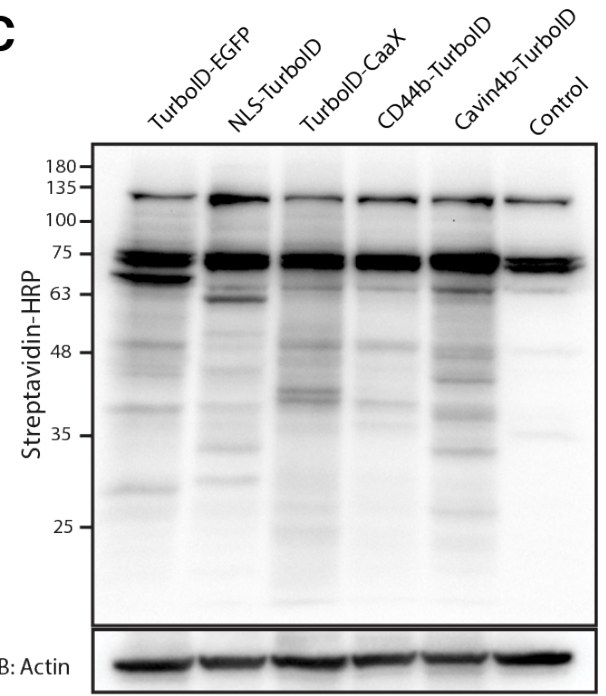

NLS-TurbolD

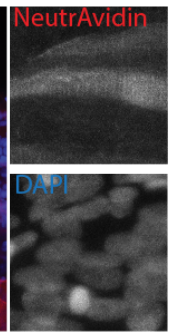

TurbolD-CaaX
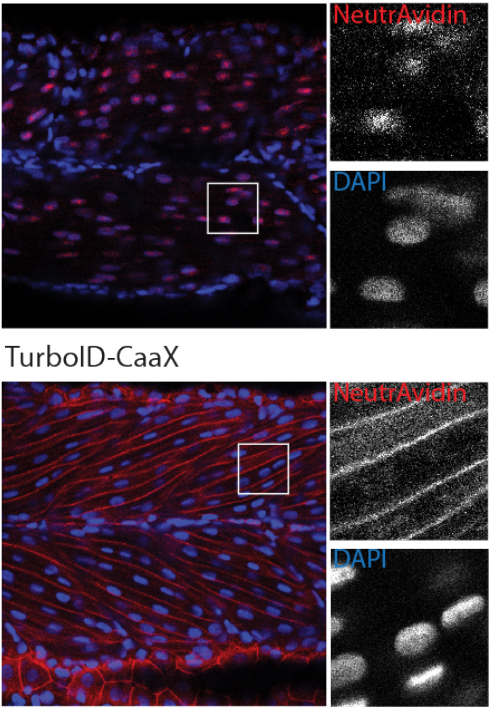

2asis

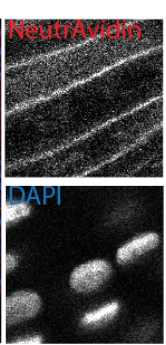

CD44b-TurbolD

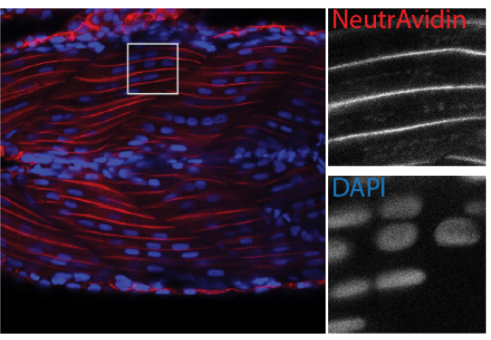

Cavin4b-TurbolD

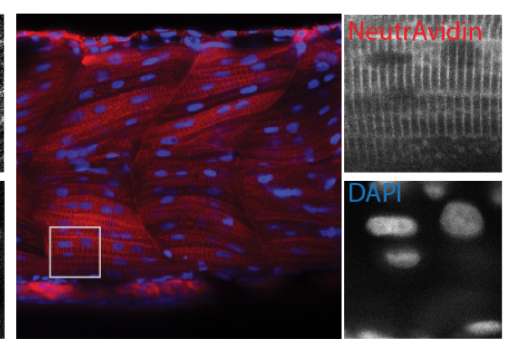

D

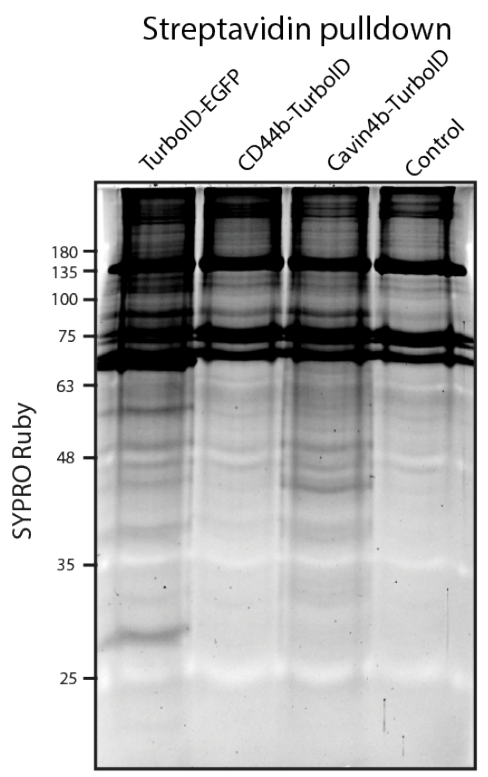

Figure 2 Spatial resolution of TurbolD-catalysed biotinylation in zebrafish embryos. (A) Schematic representation of eGFP-, NLS-, CaaX-, CD44b- and Cavin4b-tagged TurbolD constructs for MRNA injection in zebrafish embryos. TurbolD-eGFP was used as a positive control. (B) Representative images showing the distribution of biotinylated proteins in 2 dpf zebrafish embryos transiently expressing different TurbolD constructs. Negative control fish were injected with eGFP only. Fish embryos were fixed and permeabilised before NeutrAvidin-DyLight staining for biotin and DAPI staining to indicate nuclei. Regions within the white box were magnified and shown in the grey scale for NeutrAvidin and DAPI staining in the right panel; $n=3$. Scale bar represents $50 \mu \mathrm{m}$. (C) Streptavidin-HRP blots showing the "protein barcode" produced by biotinylated proteins in fish embryo transiently expressing different TurbolD constructs. Actin immunoblot served as a loading control. Each sample is a pool of 30 embryos. (D) SYPRO Ruby protein stain showing proteins isolated by streptavidin-pulldown. Approximately three hundred embryos transiently expressing each TurbolD constructs were subjected to streptavidin-pulldown after biotin incubation and embryo lysis. 
bioRxiv preprint doi: https://doi.org/10.1101/2020.11.05.370585; this version posted November 6, 2020. The copyright holder for this preprint (which was not certified by peer review) is the author/funder. All rights reserved. No reuse allowed without permission.

A


B
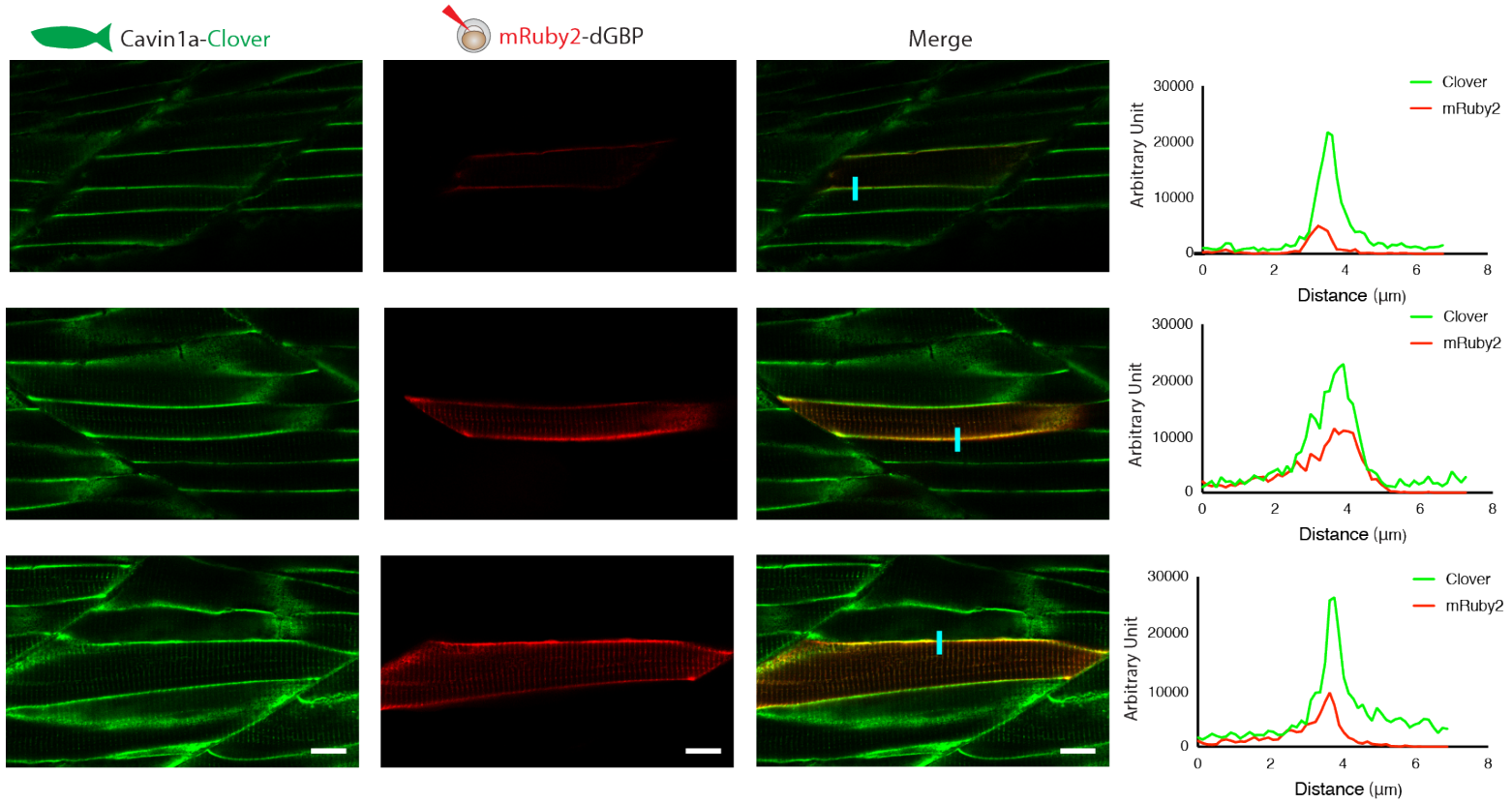

Figure 3 In vivo binding of GFP-nanobody, GBP and dGBP, in stable transgenic zebrafish embryos. (A and B) Representative images showing the colocalisation between Cavin1a-Clover and mRuby2-GBP/dGBP in live zebrafish embryos. Cavin1a-Clover zebrafish embryos transiently expressing mRuby2-tagged GBP (A) or dGBP (B). Injected embryos were imaged at $3 \mathrm{dpf}$. Line scan (indicated by the blue line) shows the fluorescent intensity of Clover and mRuby2 across the sarcolemma of mRuby2-positive muscle cells. Scale bar denotes $10 \mu \mathrm{m}$ in both (A) and (B).

\section{Development of BLITZ; Biotin Labelling in Tagged Zebrafish}

We next generated a number of fish lines expressing TurbolD-dGBP under the ubiquitous beta actin 2 (actb2) promoter (Casadei et al., 2011). To facilitate selection of appropriate transgenic integrations, we added a cytoplasmic red fluorescent protein, mKate2, as a visible reporter upstream of TurbolD-dGBP linked by a P2A sequence (Donnelly et al., 2001; Kim et al., 2011). The $P 2 A$ sequence is a short ribosome-skipping sequence which separates the upstream mKate2 from downstream TurbolD-dGBP, reducing the potential interference from the fluorescent protein. 
We first tested whether these zebrafish lines were able to catalyse specific biotinylation in tissues expressing GFP. The TurbolD-dGBP fish were outcrossed with transgenic lines expressing cytoplasmic GFP in the vasculature (kdrl:EGFP) (Beis et al., 2005) and the motor neurons (MotoN:EGFP) (Punnamoottil et al., 2015) (Figure 4A). Biotinylated proteins were examined in $3 \mathrm{dpf}$ embryos after overnight biotin incubation. In embryos co-expressing ubiquitous TurbolD-dGBP and tissuespecific GFP, TurbolD-catalysed biotinylation was detected in the intersegmental vessels and the spinal cord motor neurons in the kdrl:EGFP and MotoN:EGFP lines, respectively (Figure 4A). These results demonstrate that our TurbolD-dGBP system can produce biotinylation with tissue specificity.

To test the biotinylation on a subcellular level, the TurbolD-dGBP fish were outcrossed with Cavin1a-Clover and Cavin4a-Clover transgenic fish lines expressing Cavin1a-Clover and Cavin4a-Clover under the control of the muscle specific alpha actin promoter, acta1a. Cavin1a and Cavin4a are orthologues of human CAVIN1 and CAVIN4, which are caveolaassociated proteins involved in caveolar formation. With the same procedures, we observed clear colocalisation between biotinylated proteins and Clover-tagged cavins in muscle fibres, at the sarcolemma and T-tubules, suggesting our TurbolDdGBP system can produce proximity-dependent biotinylation with subcellular resolution. Without biotin treatment or without the expression of GFP, there was no detectable biotinylation effected by TurbolD. Notably, the specificity of GFPdirected biotinylation was not compromised in fish lines expressing higher levels of TurbolD-dGBP (Supplementary Figure $3 A)$.

We next visualised the proteins biotinylated by TurbolD-dGBP on streptavidin blots (Figure 4B). The two prominent bands representing endogenously biotinylated proteins were again observed in embryos carrying both TurboID-dGBP and Cavin1aclover; omitting the biotin supplement resulted in no exogenous biotinylation. Intriguingly, in the absence of Cavin1a-Clover, a weak biotinylation was still observed in the embryos carrying only the TurbolD-dGBP transgene, despite the level of TurbolD-dGBP being undetectable on anti-Myc immunoblot. This background labelling is likely caused by TurbolD-dGBP en route to proteasomal degradation. Using streptavidin affinity pulldown, biotinylated proteins were isolated from total fish lysates and endogenous Cavin4b, a known Cavin1 interactor (Bastiani et al., 2009), was detected in the streptavidin pulldown in addition to Cavin1a-GFP and TurbolD-dGBP (Figure 4C). Note that a trace of TurbolD-dGBP was detected in the streptavidin pulldown in the absence of GFP target with long exposure, which accounts for the weak background biotinylation in embryos expressing only TurbolD-dGBP.

\section{A comprehensive cavin proteome in skeletal muscle generated by TurbolD-dGBP}

Finally, we employed our TurbolD-dGBP system to map the proteomes associated with Cavin1 and 4 in zebrafish skeletal muscle. We crossed the TurbolD-dGBP fish with fish lines stably expressing Cavin1a-Clover, Cavin4a-Clover and Cavin4bClover in muscle. TurbolD-dGBP and cavin-Clover co-expressing embryos were selected at $2 \mathrm{dpf}$ for subsequent biotin labelling and the biotinylated proteins were analysed by liquid chromatography coupled to tandem mass spectrometry (nanoHPLC/MS MS/MS).

In total, we identified 277, 178 and 137 proteins in the Cavin1a, Cavin4a and Cavin4b samples, respectively, with high confidence (at least one high confidence peptide detected in the sample) (Supplementary file 1). An enrichment score (ES) defined as $\left(E S=\frac{\text { Protein Score }_{\text {Cavin }}}{\text { Protein Score }_{\text {Cavin }}+\text { Protein Score }_{\text {Ctrl }}}\right)$, was calculated for each identified protein. Proteins only identified in the Cavin group will have an enrichment score of 1 , while endogenous biotinylated proteins and non-specific binding proteins will tend to have an enrichment score around 0.5 (Figure $5 \mathrm{~A}-\mathrm{C}$ ). By using ES $>0.9$ as a cut-off, 83, 82, and 39 proteins were found enriched in Cavin1a, Cavin4a and Cavin4b samples, respectively (Figure 5D; Table 1; Supplementary file 2). Among the proteins detected in the Cavin1a sample, known Cavin1 interactors, such as endogenous caveolins and cavins, were identified with an ES of 1 (Figure 5A, highlighted in green). Dystrophin (Dmd), a protein associated with caveolae (Song et al., 1996; Doyle et al., 2000), was also highly enriched in the Cavin1a group (ES of 0.99). An ortholog of Pacsin3, a caveolaassociated protein required for muscle caveolar formation, (Seemann et al., 2017) was also enriched in the Cavin4b group (ES of 1.0). These interactors were undetectable in all control samples, demonstrating the high accuracy of the BLITZ system. Individual hits and general properties of putative interacting proteins are further discussed below. 
bioRxiv preprint doi: https://doi.org/10.1101/2020.11.05.370585; this version posted November 6, 2020. The copyright holder for this

preprint (which was not certified by peer review) is the author/funder. All rights reserved. No reuse allowed without permission.

A actb2: mKate2-P2A-Myc-TurbolD-dGBP $\longrightarrow$ GFP-tagged fish lines

\section{GFP}

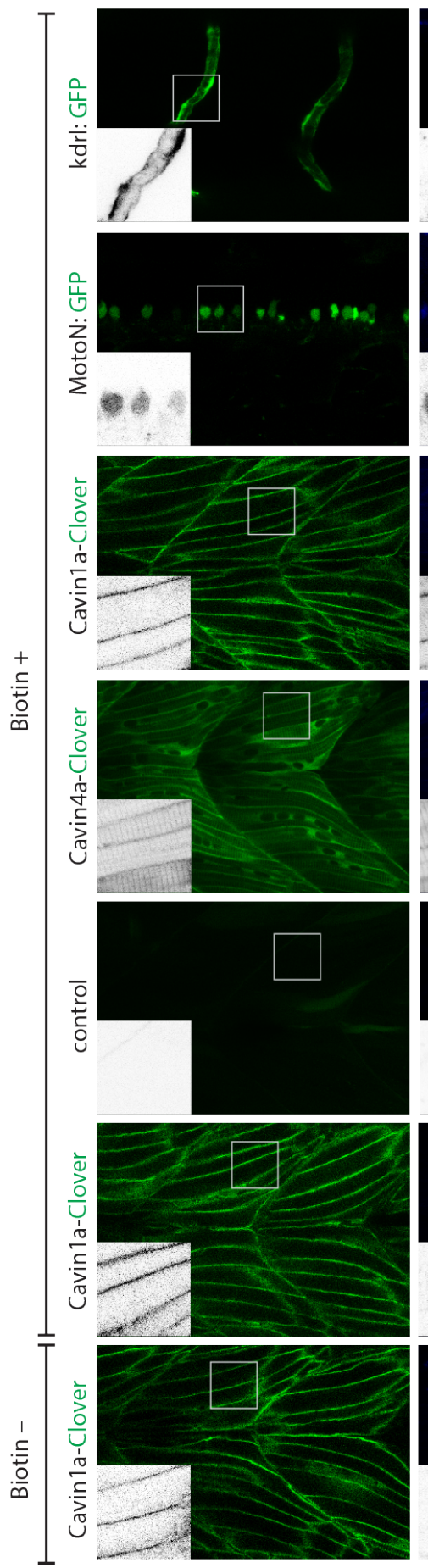

NeutrAvidin-DyLight 405


mKate2
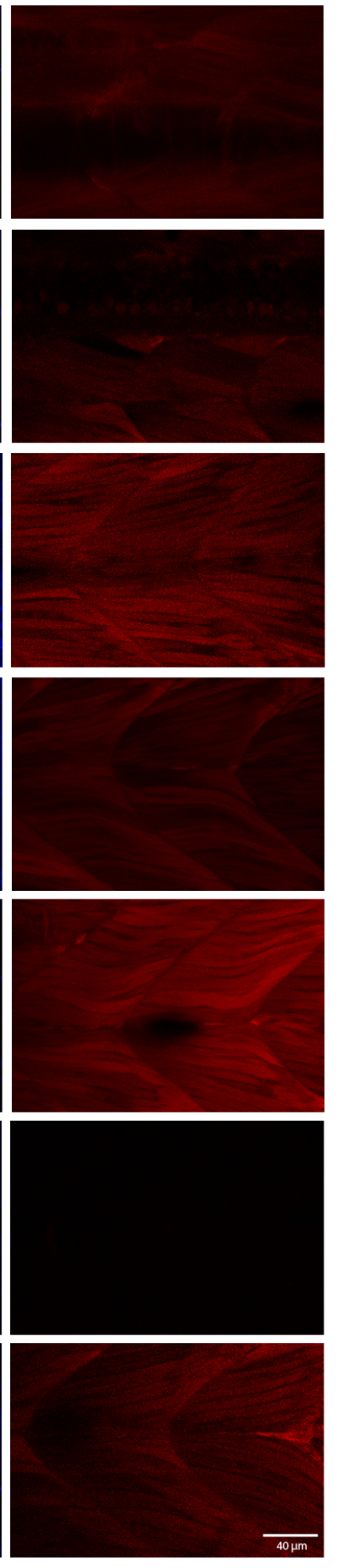

\section{B}

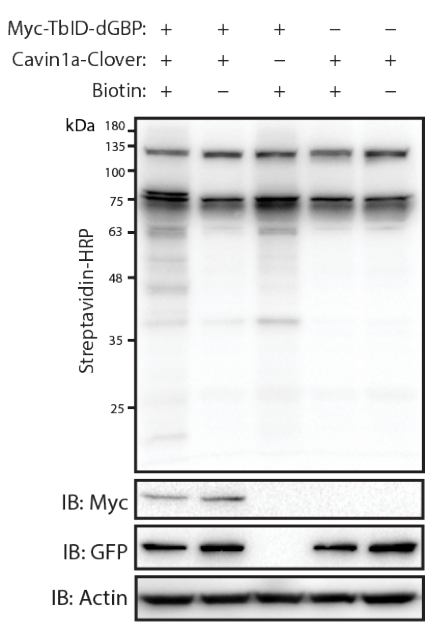

C



Figure 4 GFP-directed in vivo biotin labelling. (A) Representative images of TurbolD-dGBP catalysing GFP-dependent biotinylation in transgenic zebrafish embryos at $3 \mathrm{dpf}$. The TurboID-dGBP line was crossed with different GFP-tagged zebrafish lines: Cavin1a-Clover (plasma membrane), Cavin4a-Clover (sarcolemma and T-tubules), kdrl:eGFP (vasculature), and MotoN:eGFP (motor neurons). After biotin incubation, embryos were fixed, permeabilised and stained with NeutrAvidin to visualise the biotinylated protein. mKate2 is a fluorescent indicator for expression of TurboID-dGBP. Controls were carried out by using siblings from the same clutch without GFP expression and siblings without TurbolD expression, as well as omitting biotin incubation. The scale bar denotes $40 \mu m ; n=3$. (B) Western blot analysis showing the biotinylated proteins in 3 dpf zebrafish embryos from TurboID-dGBP outcrossing with Cavin1a-Clover line. Each sample is a pool of 30 embryos. (C) Western blot analysis of fish lysates and streptavidin pulldown with embryos from TurbolD-dGBP line outcrossing with Cavin1a-Clover line. Each pulldown sample is a pool of 200 embryos. 
bioRxiv preprint doi: https://doi.org/10.1101/2020.11.05.370585; this version posted November 6, 2020. The copyright holder for this

preprint (which was not certified by peer review) is the author/funder. All rights reserved. No reuse allowed without permission.

A

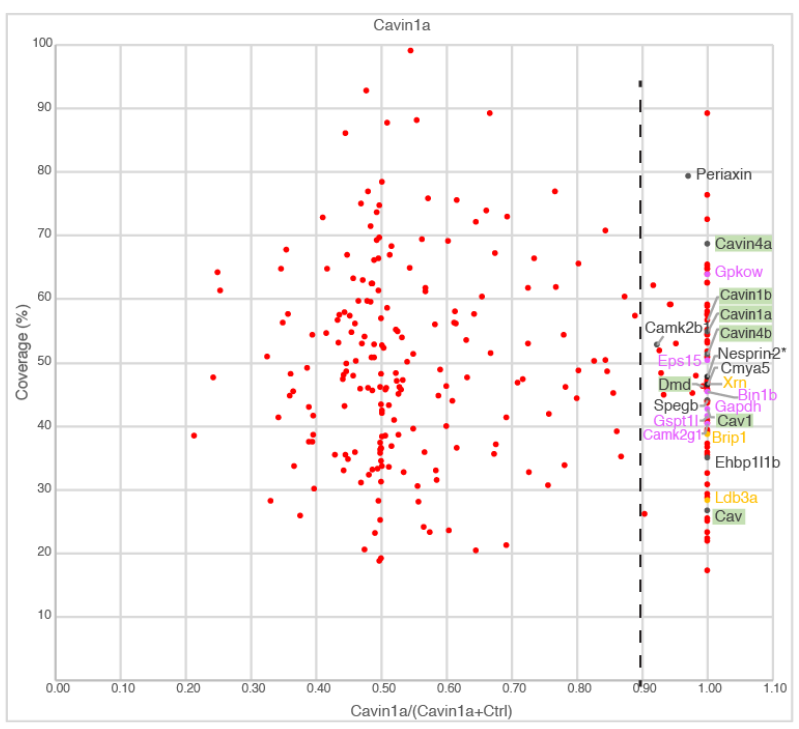

B

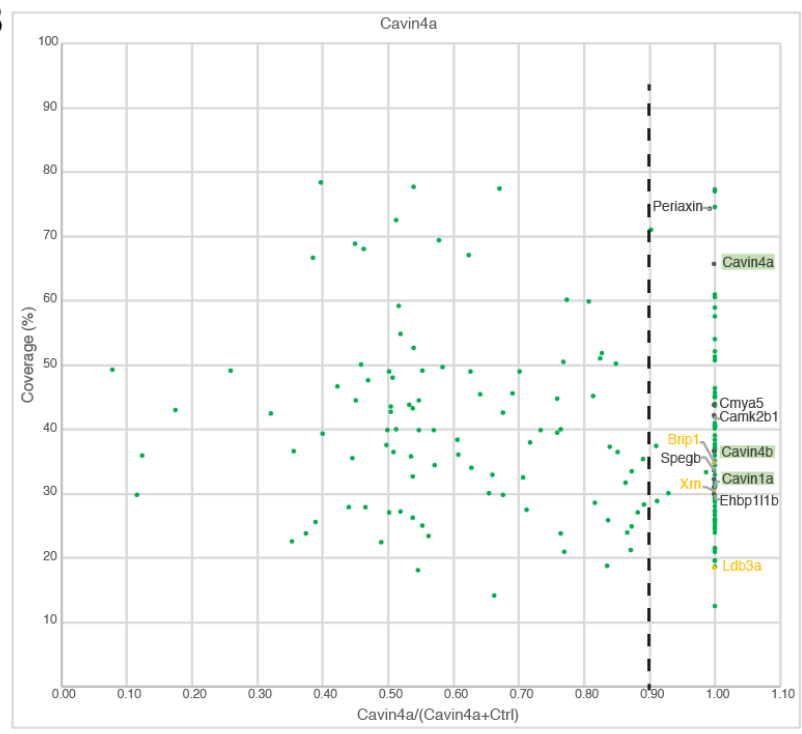

C



D

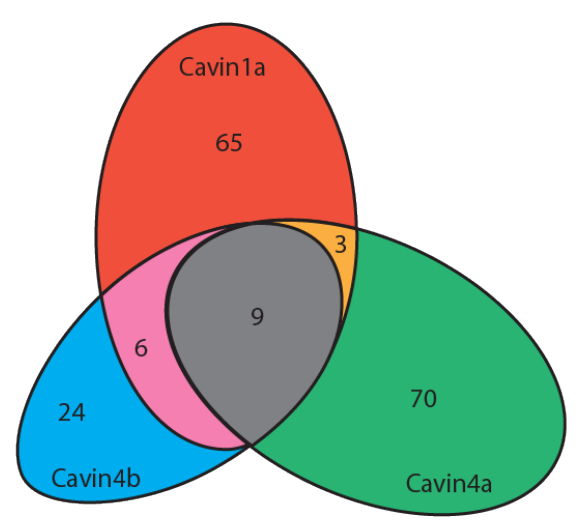

E Cellular Component Percentile



Figure 5 Proteomes identified by BLITZ system in Clover-tagged cavin zebrafish. (A, B and C) Scatter plot showing proteins identified by BLITZ with Cavin1a-Clover (A), Cavin4a-Clover (B) and Cavin4bClover $(C)$ lines. The $Y$ axis represents protein coverage and the $X$ axis represents the enrichment score. Known interactors or proteins in close proximity were highlighted in green. Protein name in black indicates the proteins were identified in all cavin samples; orange indicates the proteins were identified in both Cavin1a and Cavin $4 a$ samples; pink indicates proteins identified in both Cavin1a and Cavin $4 b$ samples. (D) Venn diagram showing the overlap of identified proteins in Cavin1a, Cavin4a and Cavin4b samples. (E) Bar graph showing the distribution of proteins at subcellular level. The cellular component information was curated from Uniport database and literature. 
bioRxiv preprint doi: https://doi.org/10.1101/2020.11.05.370585; this version posted November 6,2020 . The copyright holder for this

preprint (which was not certified by peer review) is the author/funder. All rights reserved. No reuse allowed without permission.

Table 1 Top cavin interactor candidates from Figure 5

\begin{tabular}{|c|c|c|c|c|c|}
\hline \multirow[b]{2}{*}{ Gene name } & \multicolumn{3}{|c|}{ Protein Score } & \multirow[b]{2}{*}{ Functional annotation } & \multirow[b]{2}{*}{$\begin{array}{l}\text { Subcellular } \\
\text { localisation }\end{array}$} \\
\hline & Cavin1a & Cavin4a & Cavin4b & & \\
\hline cavin $4 a$ & 26.01 & 28.01 & 24.96 & RhoA activation, myofibrillar organisation & PM, TT \\
\hline cavin1a & 23.64 & 2.27 & 4.01 & Caveola formation & PM \\
\hline cavin $4 b$ & 13.65 & 0.20 & 23.35 & Skeletal muscle development, T-tubule organisation & PM, TT \\
\hline$e h b p 1 / 1 b$ & 10.80 & 7.52 & 2.16 & Rab effector, vesicle trafficking & $E$ \\
\hline syne2* & 3.45 & 4.03 & 2.02 & $\begin{array}{l}\text { Transmission of mechanical forces, highly expressed } \\
\text { in skeletal and cardiac muscle }\end{array}$ & PM; SR, N, ZL \\
\hline cmya5 & 3.42 & 3.19 & 16.16 & $\begin{array}{l}\text { Subcellular compartmentation of protein kinase A, } \\
\text { modulating skeletal muscle regeneration }\end{array}$ & $\mathrm{N}, \mathrm{SR}$ \\
\hline spegb & 2.54 & 24.47 & 10.11 & Striated muscle-enriched protein kinase & PM, N, C \\
\hline prx & 194.25 & 136.82 & 65.73 & Scaffolding protein of dystroglycan complex & \\
\hline$c a m k 2 b 1$ & 24.33 & 9.68 & 6.02 & Calcium/calmodulin-dependent protein kinase & $\mathrm{C}, \mathrm{N}, \mathrm{PM}$ \\
\hline $1 d b 3 a$ & 2.35 & 4.02 & 0.00 & $\begin{array}{l}\text { Adapter in striated muscle to couple protein kinase } \\
\text { C-mediated signalling }\end{array}$ & $\mathrm{CS}, \mathrm{N}, \mathrm{C}, \mathrm{ZL}$ \\
\hline$x r n 1$ & 1.65 & 2.24 & 0.00 & mRNA decay & $\mathrm{C}, \mathrm{N}$ \\
\hline brip1 & 0.69 & 1.50 & 0.00 & Fanconi anemia pathway & $\mathrm{N}, \mathrm{C}$ \\
\hline camk2g1 & 12.17 & 0.00 & 6.02 & Calcium/calmodulin-dependent protein kinase & C, N, PM \\
\hline $\operatorname{bin} 1 b$ & 2.06 & 0.00 & 4.03 & T-tubules biogenesis in muscle cells & PM, TT \\
\hline eps15 & 2.02 & 0.00 & 2.02 & Regulation of cell growth & PM; E \\
\hline gspt11 & 9.77 & 0.00 & 2.01 & GTPase activity and translation termination activity & $\mathrm{C}$ \\
\hline gapdh & 2.12 & 0.00 & 2.01 & Glycolysis and assembly of cytoskeleton & $\mathrm{C}, \mathrm{CS}$ \\
\hline gpkow & 2.02 & 0.00 & 1.38 & mRNA splicing & $\mathrm{N}$ \\
\hline$d m d$ & 34.69 & 0.00 & 0.00 & $\begin{array}{l}\text { Sarcomere organization; skeletal muscle organ } \\
\text { development }\end{array}$ & PM, CS \\
\hline limch1a & 24.65 & 0.00 & 0.00 & Stress fibre assembly and focal adhesion assembly & CS \\
\hline dusp27 & 15.04 & 0.00 & 0.00 & Involved in skeletal myofibril assembly & $\mathrm{C}$ \\
\hline ank3a & 11.93 & 0.00 & 0.00 & $\begin{array}{l}\text { Required for costamere localization of DMD and } \\
\text { betaDAG1 }\end{array}$ & $\mathrm{PM}, \mathrm{TT}, \mathrm{CS}$ \\
\hline pvalb2 & 11.80 & 0.00 & 0.00 & Involved in relaxation after contraction in muscle & $\mathrm{C}, \mathrm{N}$ \\
\hline gspt1 & 8.92 & 0.00 & 0.00 & Translation termination activity & $\mathrm{C}$ \\
\hline camk2d1 & 8.75 & 0.00 & 0.00 & Calcium/calmodulin-dependent protein kinase & $\mathrm{C}, \mathrm{N}, \mathrm{PM}$ \\
\hline larp4b & 7.40 & 0.00 & 0.00 & Stimulates mRNA translation & $\mathrm{C}$ \\
\hline desma & 6.97 & 0.00 & 0.00 & $\begin{array}{l}\text { Regulation of sarcomere organization and skeletal } \\
\text { muscle tissue development }\end{array}$ & PM, N, ZL \\
\hline unc $45 b$ & 5.92 & 0.00 & 0.00 & Sarcomere formation in muscle cell development & $\mathrm{ZL}$ \\
\hline$n m e 2 b .2$ & 4.34 & 0.00 & 0.00 & $\begin{array}{l}\text { G protein-coupled receptor endocytosis and gene } \\
\text { expression }\end{array}$ & $\mathrm{N}, \mathrm{CP}$ \\
\hline neb & 4.26 & 0.00 & 0.00 & Muscle fiber development & CS \\
\hline palm2 & 4.15 & 0.00 & 0.00 & Regulation of cell shape & PM \\
\hline stx4 & 4.02 & 0.00 & 0.00 & Intracellular protein transport & PM \\
\hline xirp2a & 3.61 & 0.00 & 0.00 & $\begin{array}{l}\text { Actin cytoskeleton organization; cardiac and } \\
\text { skeletal muscle development }\end{array}$ & $\mathrm{ZL}$ \\
\hline xirp $2 b$ & 3.37 & 0.00 & 0.00 & $\begin{array}{l}\text { Actin cytoskeleton organization; cardiac and } \\
\text { skeletal muscle development }\end{array}$ & $\mathrm{ZL}$ \\
\hline vim & 3.18 & 0.00 & 0.00 & Class-III intermediate filaments & $\mathrm{PM}, \mathrm{N}, \mathrm{CS}$ \\
\hline crybb1 & 2.85 & 0.00 & 0.00 & Structural constituent of eye lens & \\
\hline cavin $1 b$ & 2.61 & 0.00 & 0.00 & Caveola formation and notochord development & $\mathrm{PM}, \mathrm{C}$ \\
\hline $\operatorname{tln} 2 a$ & 2.57 & 0.00 & 0.00 & A major component of focal adhesion & PM, CS \\
\hline cast & 2.44 & 0.00 & 0.00 & $\begin{array}{l}\text { Calcium-dependent cysteine-type endopeptidase } \\
\text { inhibitor }\end{array}$ & C \\
\hline atp5fa1 & 2.42 & 0.00 & 0.00 & ATP synthesis coupled proton transport & $\mathrm{M}, \mathrm{PM}$ \\
\hline taf6 & 2.39 & 0.00 & 0.00 & RNA polymerase II preinitiation complex assembly & $\mathrm{N}$ \\
\hline mylpfa & 2.17 & 0.00 & 0.00 & Ca2+ binding activity & $\mathrm{C}, \mathrm{CS}$ \\
\hline dars & 2.17 & 0.00 & 0.00 & Involved in aspartyl-tRNA aminoacylation & $\mathrm{C}$ \\
\hline$e e f 2 b$ & 2.10 & 0.00 & 0.00 & $\begin{array}{l}\text { Catalysing GTP-dependent ribosomal translocation } \\
\text { step during translation elongation }\end{array}$ & $\mathrm{CP}, \mathrm{N}$ \\
\hline rps6 & 2.09 & 0.00 & 0.00 & $\begin{array}{l}\text { Structural constituent of ribosome, controlling cell } \\
\text { growth and proliferation }\end{array}$ & C, ER, N \\
\hline rps23 & 2.03 & 0.00 & 0.00 & Structural constituent of ribosome & C, ER \\
\hline nocta & 2.03 & 0.00 & 0.00 & Circadian regulation of gene expression & $\mathrm{N}, \mathrm{M}$ \\
\hline clen5a & 2.01 & 0.00 & 0.00 & Proton-coupled chloride transporter & Golgi, PM, ED \\
\hline tnni2a.4 & 2.01 & 0.00 & 0.00 & Myofibril assembly; muscle contraction & $\mathrm{CS}, \mathrm{C}, \mathrm{N}$ \\
\hline sncga & 2.01 & 0.00 & 0.00 & $\begin{array}{l}\text { Activation of the MAPK and Elk-1 signal } \\
\text { transduction pathway }\end{array}$ & CS \\
\hline$m d h 1 a b$ & 2.01 & 0.00 & 0.00 & Involved in carbohydrate metabolic process & $\mathrm{C}$ \\
\hline
\end{tabular}


bioRxiv preprint doi: https://doi.org/10.1101/2020.11.05.370585; this version posted November 6, 2020. The copyright holder for this preprint (which was not certified by peer review) is the author/funder. All rights reserved. No reuse allowed without permission.

\begin{tabular}{|c|c|c|c|c|c|}
\hline enpp6 & 2.01 & 0.00 & 0.00 & $\begin{array}{l}\text { Involved in choline metabolic process and lipid } \\
\text { metabolic process }\end{array}$ & PM \\
\hline cav1 & 2.00 & 0.00 & 0.00 & $\begin{array}{l}\text { Caveola formation; endocytosis; cholesterol } \\
\text { distribution; cell signalling }\end{array}$ & PM, Golgi \\
\hline Iypla2 & 2.00 & 0.00 & 0.00 & Involved in protein depalmitoylation & c \\
\hline zgc:158296 & 2.00 & 0.00 & 0.00 & Caveolin paralog, involved in caveola assembly & PM, Golgi \\
\hline ahnak & 0.00 & 50.43 & 0.00 & Regulation of RNA splicing, interacts with dysferlin & $\mathrm{PM}, \mathrm{TT}, \mathrm{N}, \mathrm{C}$, \\
\hline gn/3 & 0.00 & 16.02 & 0.00 & Maintain the proliferative capacity of stem cells & $\mathrm{N}$ \\
\hline histh1/3 & 0.00 & 8.14 & 0.00 & Nucleosome assembly & $\mathrm{N}$ \\
\hline hp1bp3 & 0.00 & 4.08 & 0.00 & Heterochromatin organization & $\mathrm{N}$ \\
\hline$d h \times 37$ & 0.00 & 2.43 & 0.00 & $\begin{array}{l}\text { Release of the U3 snoRNP from pre-ribosomal } \\
\text { particles }\end{array}$ & $\mathrm{N}$ \\
\hline top $2 b$ & 0.00 & 2.27 & 0.00 & DNA topoisomerase & $\mathrm{N}$ \\
\hline hpсa & 0.00 & 2.26 & 0.00 & Regulation of voltage-dependent calcium channels & PM, C \\
\hline osbpl2a & 0.00 & 2.24 & 0.00 & Lipid transport & PM, C \\
\hline grin2ab & 0.00 & 2.12 & 0.00 & Regulation of postsynaptic membrane potential & PM \\
\hline $\begin{array}{l}\text { si:ch211- } \\
42 i 6.2\end{array}$ & 0.00 & 2.09 & 0.00 & $\begin{array}{l}\text { Intracellular signal transduction in innate immunity } \\
\text { and inflammation }\end{array}$ & $E R, N$ \\
\hline$e i f 5 b$ & 0.00 & 2.08 & 0.00 & Involved in translation initiation & c \\
\hline$m c f 2 a$ & 0.00 & 2.08 & 0.00 & $\begin{array}{l}\text { Guanine nucleotide exchange factor (GEF) that } \\
\text { modulates the Rho family of GTPases }\end{array}$ & C, PM \\
\hline nop58 & 0.00 & 2.08 & 0.00 & 605 ribosomal subunit biogenesis & $\mathrm{N}$ \\
\hline$r p s 8 b$ & 0.00 & 2.06 & 0.00 & Component of the ribosome & c \\
\hline scinla & 0.00 & 2.04 & 0.00 & $\begin{array}{l}\text { Actin filament binding and phosphatidylinositol-4,5- } \\
\text { bisphosphate binding }\end{array}$ & CS \\
\hline fubp3 & 0.00 & 2.03 & 0.00 & $\begin{array}{l}\text { Predicted to be involved in regulation of } \\
\text { transcription }\end{array}$ & N \\
\hline sorbs $2 a$ & 0.00 & 2.01 & 0.00 & $\begin{array}{l}\text { Adapter protein to assemble signaling complexes in } \\
\text { stress fibers }\end{array}$ & PM, ZL \\
\hline arhgef $25 b$ & 0.00 & 1.53 & 0.00 & $\begin{array}{l}\text { Involved in regulation of Rho protein signal } \\
\text { transduction; Involved in skeletal myogenesis }\end{array}$ & PM \\
\hline acta 2 & 0.00 & 0.00 & 12.04 & Constituent of contractile apparatus & CS \\
\hline zgc:153405 & 0.00 & 0.00 & 10.52 & Predicted to be involved in DNA packaging & $\mathrm{N}$ \\
\hline$r s / 1 d 1$ & 0.00 & 0.00 & 6.01 & $\begin{array}{l}\text { A pro-apoptotic regulator in response to DNA } \\
\text { damage }\end{array}$ & $\mathrm{N}$ \\
\hline sept5a & 0.00 & 0.00 & 4.01 & $\begin{array}{l}\text { Cytoskeleton-dependent cytokinesis; and regulation } \\
\text { of exocytosis }\end{array}$ & CS, C \\
\hline$d n m 1 b$ & 0.00 & 0.00 & 3.01 & $\begin{array}{l}\text { Vesicular trafficking processes. Involved in receptor- } \\
\text { mediated endocytosis }\end{array}$ & C \\
\hline ehbp1/1a & 0.00 & 0.00 & 2.09 & Rab effector, involved in vesicle trafficking & $E, C S$ \\
\hline hspa1b & 0.00 & 0.00 & 2.06 & Protein chaperone & $C, P M, N, M$ \\
\hline$d k c 1$ & 0.00 & 0.00 & 2.05 & Ribosome biogenesis and telomere maintenance & $\mathrm{N}, \mathrm{C}$ \\
\hline $\mathrm{lbr}$ & 0.00 & 0.00 & 2.01 & Involved in cholesterol biosynthesis & $\mathrm{N}$ \\
\hline zgc:91999 & 0.00 & 0.00 & 2.01 & $\begin{array}{l}\text { Pacsin3 homolog, involved in cytoskeleton } \\
\text { organization; plasma membrane tubulation; and } \\
\text { regulation of endocytosis. }\end{array}$ & PM, E \\
\hline smap1 & 0.00 & 0.00 & 2.00 & Regulation of clathrin-dependent endocytosis & PM \\
\hline$r p / 3$ & 0.00 & 0.00 & 1.92 & A component of cytoplasmic ribosomes & C \\
\hline scn1laa & 0.00 & 0.00 & 1.69 & Membrane depolarization during action potential & PM \\
\hline gas $2 a$ & 0.00 & 0.00 & 1.56 & Apoptotic process and in limb myogenesis & CS \\
\hline stc1 & 0.00 & 0.00 & 1.30 & Cellular calcium ion homeostasis in cardiomyocytes & PM, N \\
\hline alyref & 0.00 & 0.00 & 1.15 & Export adapter involved in nuclear export of mRNA & $\mathrm{N}, \mathrm{C}$ \\
\hline jak3 & 0.00 & 0.00 & 0.36 & Non-receptor tyrosine kinase & CS \\
\hline
\end{tabular}

\section{Discussion}

\section{Advantages of BLITZ in proteomic mapping}

In this study, we have developed BLITZ (Biotin Labelling In Tagged Zebrafish): a modular system for in vivo proteomic mapping (Figure 6). This system utilises the advantages of BiolD at capturing weak or transient interactions in living cells, but extends its application to an in vivo setting, enabling interactome investigation at specific developmental stages under physiological conditions, and potentially in disease models. The system also has several advantages over conventional BiolD methods for studying the proteome and interactome. 
Firstly, BLITZ does not require extensive molecular biology steps to produce numerous expression constructs, or laborious embryonic manipulation. It instead relies on simple crossing of a TurbolD-dGBP line with an existing GFP-tagged fish line of choice; a plethora of such lines currently exist in stock centres globally and, with the advent of nuclease directed genome editing, this number is rapidly increasing. Secondly, BLITZ enables cell- and tissue-specific proteomic studies, since the stability of TurbolD-dGBP is dependent on its binding to GFP targets. Non-specific biotin labelling in tissues that do not express GFP-tagged constructs is avoided. Thirdly, our TurbolD-dGBP system has the potential to be used with knock-in fish lines carrying a GFP fusion protein at the endogenous locus of a POI. This will enable the application of BiolD to study proteomic associations with endogenous proteins, which, to our knowledge, has not been achieved by conventional BiolD methods. Finally, the modularity of the BLITZ system could be advantageous for use in established tissue culture systems using existing GFP expression vectors or/and knock-in cell lines, as well as extended to other organisms.

The use of the BLITZ system also comes with some caveats. Unlike the traditional BiolD approach using a direct fusion of the biotin ligase with the bait protein, our system targets TurbolD to the POI through the binding of dGBP nanobody to GFP. In this case, the indirect binding increases the physical distance between biotin ligase and the POI, which could potentially enlarge the effective labelling radius and include more non-interacting neighbouring proteins. However, we have previously shown that the use of a GFP-directed nanobody to target a genetically encoded peroxidase (APEX2) for protein localisation does not appear to compromise the fidelity of labelling: APEX2 staining was rarely observed beyond $25 \mathrm{~nm}$ from the site of POI (Ariotti et al., 2015). It is also possible that the binding of the biotin ligase-nanobody with the GFP-tagged POI could perturb the localisation of the $\mathrm{POI}$, either by masking interacting surfaces or simply due to the larger size of a complex. For this reason, we routinely examine the distribution of the GFP-tagged POI both with and without biotin ligase-dGBP expression as well as the distribution of biotinylated proteins using fluorescent neutravidin staining. Since our in vivo system is based on the simple crossing of heterozygous transgenic lines, every new clutch contains offspring with every possible combination of alleles, and the appropriate internal controls can be sorted by fluorescence.

\section{Application of BLITZ to the identification of cavin-association networks in muscle}

Cavin family proteins are key components of the caveolar coat complex associated with the inner leaflet of the plasma membrane. Cavin1 is present in all tissues and is essential for caveolar formation and function. Cavin2, 3 and 4 show more restricted tissue distributions with Cavin4 being specific to skeletal and cardiac muscle (reviewed in Parton et al., 2018). In the zebrafish, Cavin1 and 4 are each duplicated such that four loci exist; Cavin1a/b and Cavin4a/b. Cavin1a and b show spatially distinct expression patterns with Cavin $1 b$ being largely restricted to the developing notochord whereas Cavin1a, 4a and $4 \mathrm{~b}$ are all highly expressed in skeletal muscle (Hill et al., 2008; Lo et al., 2015; Housley et al., 2016). In this study we used the BLITZ system to identify putative interactors for all three skeletal muscle cavins, and identified sets of putative interactors both unique and common to all three proteins.

The majority of proteins identified for all cavin proteomes were muscle-enriched factors and plasma membrane proteins. We also saw a specific enrichment of known caveola-associated proteins consistent with initial expectations (Table 1; Supplementary File 2). However, the cavin proteomes also contained a disproportionate number of nuclear proteins, such as Brip1, Xrn1, Taf6. In cultured cells, cavins have been shown to be released from the plasma membrane in response to external stimuli (such as mechanical stress) and are able to bind intracellular targets in variety of subcellular locations to regulate processes such as ribosomal RNA transcription and apoptosis (Liu and Pilch, 2016; McMahon et al., 2019). In addition, in the absence of Cavin1, in knockout mouse muscle, Cavin4 has been shown to localise predominantly to the nucleus rather than the sarcolemma (Lo et al., 2015).

What processes might Cavin1 and Cavin4 be regulating? We know that loss of Cavin1 causes lipodystrophy and muscular dystrophy in humans. Patient and animal muscle shows hypertrophied muscle fibres (Hayashi et al., 2009; Rajab et al., 2010; Ding et al., 2017). Cavin4 mutations have been described in dilated cardiomyopathy patients and there is evidence that Cavin4 recruits ERK in cardiomyocytes (Rodriguez et al., 2011; Ogata et al., 2014). Thus, there is supporting data for the positive regulation of hypertrophy in skeletal muscle fibres by Cavin1, and in cardiomyocytes by Cavin4. The cavin proteome showed an enrichment of protein kinases, such as calcium/calmodulin-dependent protein kinase II (CaMKII). CaMKII regulates $\mathrm{Ca}^{2+}$ signalling and plays an important role in the development of cardiac hypertrophy through the ERK signalling pathway (Illario et al., 2003; Cipolletta et al., 2010; Cipolletta et al., 2015). The activation of CaMKII can be induced by exercise in skeletal muscle, with the activation level proportional to the intensity of exercise (Rose et al., 2006). 
bioRxiv preprint doi: https://doi.org/10.1101/2020.11.05.370585; this version posted November 6, 2020. The copyright holder for this preprint (which was not certified by peer review) is the author/funder. All rights reserved. No reuse allowed without permission.

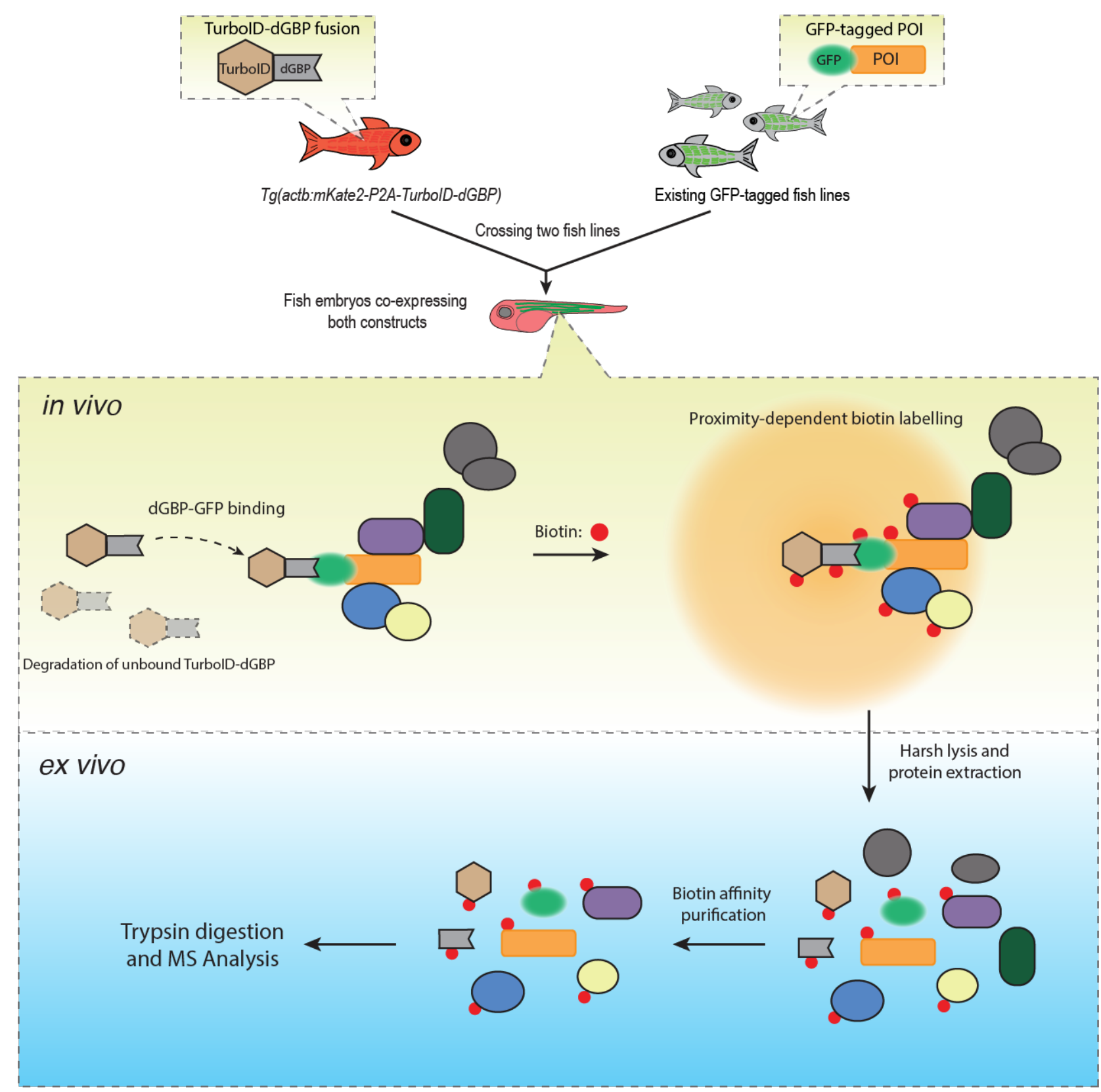

Figure 6 A schematic overview of the BLITZ system. The TurboID-dGBP lines can be crossed with existing GFP-tagged lines. In the embryos carrying both transgenes, the binding between $d G B P$ and GFP stabilise TurboID- $d G B P$, which leads to proximity biotinylation around the GFPtagged POIs. The unbound TurbolD-dGBP will be rapidly degraded by the ubiquitin proteasome system, which minimises non-specific labelling when dGBP-GFP binding saturates, as well as achieving tissue specificity by averting labelling in cells/tissues that do not express GFP. The biotin labelled proteins can be isolated by biotin affinity purification and identified by MS analysis.

In this study, BLITZ revealed several putative cavin interactors that have also been shown to be involved in cardiomyopathies and/or skeletal myopathies, including the membrane protein Dystrophin (Deconinck and Dan, 2007), the intermediate filament protein Desmin (Hnia et al., 2015), and the triad associated proteins Bin1 (Nicot et al., 2007), Cypher/ZASP (Selcen and Engel, 2005) and SPEG (Agrawal et al., 2014). Genetic ablation of zebrafish Cavin4b causes aberrant T-tubules in skeletal muscle (Housley et al., 2016). It is possible that Cavin4 may be involved in T-tubule formation through interaction with triad associated proteins, such as Bin1.

Overall, our BLITZ system enables the in vivo identification of protein interactors in a cell- and tissue- specific manner, with high precision. We demonstrated the applicability of this approach in diverse cell types including neurons and vascular endothelial cells and applied the BLITZ system to identify factors associated with cavin family proteins in differentiated skeletal muscle. BLITZ provides a versatile and valuable tool for proteomic discovery using the zebrafish model, but also has the potential for application in other in vivo contexts that to date have been challenging or intractable. 
bioRxiv preprint doi: https://doi.org/10.1101/2020.11.05.370585; this version posted November 6, 2020. The copyright holder for this preprint (which was not certified by peer review) is the author/funder. All rights reserved. No reuse allowed without permission.

\section{Materials and methods}

Table 2

\begin{tabular}{|c|c|c|}
\hline REAGENT or RESOURCE & SOURCE & IDENTIFIER \\
\hline E3 Media & & $\mathrm{N} / \mathrm{A}$ \\
\hline Phenol Red & Sigma-Aldrich & P0290-100ML \\
\hline NeutrAvidin-DyLight 405 & Invitrogen & 22831 \\
\hline NeutrAvidin-DyLight 550 & Invitrogen & 84606 \\
\hline Pronase & Roche & 10165921001 \\
\hline Sodium deoxycholate & Sigma-Aldrich & D6750-10G \\
\hline Tris & Astral Scientific & BIO3094T-1KG \\
\hline $\mathrm{NaCl}$ & EMD Millipore & 1064045000 \\
\hline NP-40 & Sigma-Aldrich & 18896-50ML \\
\hline EDTA & Astral Scientific & BIOEB0185-500G \\
\hline Complete ${ }^{T M}$ Protease Inhibitor Cocktail & Sigma-Aldrich & 11836145001 \\
\hline Pierce $^{T M}$ BCA protein assay kit & Thermo Scientific & 23225 \\
\hline Paraformaldehyde & Sigma-Aldrich & P6148-500G \\
\hline Proteinase $\mathrm{K}$ & Invitrogen & 25530015 \\
\hline PBS tablets & Medicago & 09-8912-100 \\
\hline Triton-X100 & Sigma-Aldrich & T9284-500ML \\
\hline Tween 20 & Sigma-Aldrich & P1379-500ML \\
\hline DAPI & Sigma-Aldrich & D9542-5MG \\
\hline Bolt $^{T M}$ LDS sample buffer (4X) & Invitrogen & B0008 \\
\hline Streptavidin-HRP & Abcam & ab7403 \\
\hline Mouse anti-Myc & Cell Signaling Technology & $2276 S$ \\
\hline Mouse anti-Actin & EMD Millipore & MAB1501 \\
\hline Rabbit anti-Cavin $4 \mathrm{~b}$ & Boster Biological Technology & DZ33949 \\
\hline Clarity $^{\mathrm{TM}}$ Western ECL Substrate & Bio-Rad & 1705061 \\
\hline PD-10 desalting column & GE Healthcare & $17-0851-01$ \\
\hline Dynabeads $^{\mathrm{TM}} \mathrm{MyOne}^{\mathrm{TM}}$ Streptavidin C1 & Invitrogen & 65001 \\
\hline LoBind tube & Eppendorf & 022431048 \\
\hline Blot $^{\mathrm{TM}} 4-12 \%$ Bis-Tris Plus precast gels & Invitrogen & NW04120BOX \\
\hline SYPRO ${ }^{\text {TM }}$ Ruby Protein Gel Stain & Invitrogen & S12000 \\
\hline Instant $B / u e^{T M}$ & Expedeon & ISB1L-1L \\
\hline Agarose, low gelling temperature & Sigma-Aldrich & A9414-100G \\
\hline Trypsin/Lys-C Mix, Mass Spec Grade & Promega & V5073 \\
\hline
\end{tabular}

\section{Zebrafish husbandry}

Zebrafish were raised and maintained according to institutional guidelines (Techniplast recirculating system, 14-h light/10-h dark cycle, University of Queensland, UQ). Adults ( $90 \mathrm{dpf}$ above) were housed in 3 or $8 \mathrm{~L}$ tanks with flow at $28.5^{\circ} \mathrm{C}$ and embryos up to $5 \mathrm{dpf}$ were housed in $8 \mathrm{~cm}$ Petri dishes in standard $\mathrm{E} 3$ media $\left(5 \mathrm{mM} \mathrm{NaCl}, 0.17 \mathrm{mM} \mathrm{KCl}, 0.33 \mathrm{mM} \mathrm{CaCl} 2\right.$ and $\mathrm{MgSO}_{4}$ ) at $28^{\circ} \mathrm{C}$ (incubated in the dark) (Westerfield, 2007). All experiments were approved by the University of Queensland Animal Ethics Committee. The following zebrafish strains were used in this study: wild-type (TAB), an AB/TU line generated in UQBR Aquatics (UQ Biological Resources), Tg(acta1:cavin1aClover), Tg(acta1:cavin4a-Clover), Tg(acta1:Cavin4b-Clover), Tg(actb2:mKate2-P2A-TurbolD-dGBP), Tg(kdrl:eGFP) and Tg(MotoN:GFP). The developmental stages of zebrafish used in experiments are prior to specific sex determination. All zebrafish used in experiment were healthy, not involved in previous procedures and drug or test naïve.

\section{DNA constructs and transgenic fish lines}

The protein sequence of TurboID and MiniTurbo was constructed according to Branon et al., 2018 while the protein sequence of BASU was designed according to Ramanathan et al., 2018. The coding sequences of TurbolD, MiniTurbo and BASU were ordered from IDT as gene fragment with codon optimised for zebrafish expression (https://sg.idtdna.com). The expression of biotin ligases was driven by a ubiquitous promoter of actb2 (Higashijima et al., 1997; Casadei et al., 2011). A red fluorescent reporter, mKate2, was indirectly linked into the Nterminus of biotin ligase through a self-cleaving P2A sequence (Shcherbo et al., 2009; Kim et al., 2011). Promoter, fluorescent report and biotin ligase were cloned into destination vector using Gateway cloning system. All fish lines were generated by using Tol2kit system according to established methods (Kawakami, 2004; Kwan et al., 2007). In brief, plasmid constructs for generating transgenic lines were coinjected with tol2 mRNA into one-cell-stage WT zebrafish embryos (Nusslein-Volhard and Dahm, 2002). Injected Fos were raised and screened for founders producing positive $F_{1} s$ with Mendelian frequencies, indicative of single genomic integration. Positive $F_{1} s$ grown to reproductive age were used for our experiments. Stable lines were maintained as heterozygotes. All stable lines used are given in table below. 
bioRxiv preprint doi: https://doi.org/10.1101/2020.11.05.370585; this version posted November 6, 2020. The copyright holder for this preprint (which was not certified by peer review) is the author/funder. All rights reserved. No reuse allowed without permission.

Table 3

\begin{tabular}{|c|c|c|}
\hline Transgenic Fish lines & Details & reference \\
\hline TurbolD-dGBP & Tg(actb2:mKate2-P2A-TurbolD-dGBP) & generated in this paper \\
\hline Cavin1a-Clover & Tg(acta1:Cavin1a-Clover) & generated in this paper \\
\hline Cavin4a-Clover & Tg(acta1:Cavin4a-Clover) & generated in this paper \\
\hline Cavin4b-Clover & Tg(acta1:Cavin4b-Clover) & generated in this paper \\
\hline Kdrl:GFP & $T g(k d r l: E G F P)$ & (Beis et al., 2005) \\
\hline MotoN:GFP & $\operatorname{Tg}(\operatorname{miR218:EGFP)}$ & (Punnamoottil et al., 2015) \\
\hline Constructs & Addgene identifier & \\
\hline $\begin{array}{l}\text { pT3TS-BASU-EGFP (constructs for } \\
\text { RNA) }\end{array}$ & Pending & \\
\hline $\begin{array}{l}\text { pT3TS-TurbolD-EGFP (constructs for } \\
\text { RNA) }\end{array}$ & Pending & \\
\hline $\begin{array}{l}\text { pT3TS-miniTurbo-EGFP (constructs for } \\
\text { RNA) }\end{array}$ & Pending & \\
\hline $\begin{array}{l}\text { pT3TS-TurbolD-CaaX (constructs for } \\
\text { RNA) }\end{array}$ & Pending & \\
\hline $\begin{array}{l}\text { pT3TS-NLS-TurbolD (constructs for } \\
\text { RNA) }\end{array}$ & Pending & \\
\hline $\begin{array}{l}\text { pT3TS-CD } 44 b \text {-TurbolD (constructs for } \\
\text { RNA) }\end{array}$ & Pending & \\
\hline $\begin{array}{l}\text { pT3TS-Cavin } 4 b \text {-TurbolD (constructs for } \\
\text { RNA) }\end{array}$ & Pending & \\
\hline $\begin{array}{l}\text { Cavin1a-Clover (construct for } \\
\text { generating stable fish line) }\end{array}$ & Pending & \\
\hline $\begin{array}{l}\text { Cavin4a-Clover (construct for } \\
\text { generating stable fish line) }\end{array}$ & Pending & \\
\hline $\begin{array}{l}\text { Cavin } 4 b \text {-Clover (construct for } \\
\text { generating stable fish line) }\end{array}$ & Pending & \\
\hline mRuby2-GBP(DNA construct) & Pending & \\
\hline mRuby2-dGBP(DNA construct) & Pending & \\
\hline $\begin{array}{l}\text { mKate2-P2A-TurbolD-dGBP } \\
\text { (constructs for generating stable fish } \\
\text { line) }\end{array}$ & Pending & \\
\hline
\end{tabular}

Transient expression by DNA/RNA microinjection

DNA plasmid and RNA transcript for injection were diluted to final concentration of $30 \mathrm{ng} / \mu \mathrm{l}$ and $200 \mathrm{ng} / \mu \mathrm{l}$, respectively, with addition of Phenol Red (Sigma-Aldrich) as injection tracer. A bolus of approximately $1 / 5$ of the total cell diameter was injected into each embryo. For DNA injection, the bolus was injected into the cell of embryos at single cell stage ( 5 to $25 \mathrm{~min}$-post-fertilisation). For RNA injection, the bolus was injected into the yolk of the embryos up until 2-ell stage. The RNA transcript was synthesised by mMESSAGE mMACHINE ${ }^{\top M}$ T3 (Invitrogen) according to manufacturer's instruction. The RNA transcripts were tagged with poly(A) tail using Poly(A) Tailing Kit (Invitrogen) to extend the stability of mRNA in zebrafish embryos.

\section{In vivo biotin labelling}

Embryos at indicated developmental stage were incubated in the E3 media supplemented with $500 \mu \mathrm{M}$ biotin for $18 \mathrm{~h}$ to initiate biotinylation in vivo. For embryos before hatching, a dechorionation step was carried out by using Pronase (Roche, $100 \mu \mathrm{g} / \mathrm{ml}$ in E3 media for $40 \mathrm{~min}$ at $28^{\circ} \mathrm{C}$ ) prior to the biotin incubation. After biotin incubation, embryos were washed for 40 min with two changes of standard E3 media to remove unincorporated biotin before subsequent immunostaining or protein extraction.

\section{Zebrafish embryos protein extraction}

Fish embryos after in vivo biotin labelling were deyolked by mechanical disruption through a $200 \mu$ l pipette tips in calcium-free Ringer's solution followed by two changes of solution at $4{ }^{\circ} \mathrm{C}$. The deyolked embryos was lysed by brief sonication in RIPA buffer ( $50 \mathrm{mM}$ Tris- $\mathrm{HCl}$, pH 7.5; 150 mM NaCl; $1 \%$ NP-40; 0.1\% SDS; 5 mM EDTA; 0.5\% Na-deoxycholate,) with freshly added cOmplele ${ }^{\mathrm{TM}}$ Protease Inhibitor. Lysates were further solubilised at $4{ }^{\circ} \mathrm{C}$ with rotation for $30 \mathrm{~min}$. Insoluble material was removed by centrifugation at $14,000 \times \mathrm{g}$ for $10 \mathrm{~min}$ at $4{ }^{\circ} \mathrm{C}$, and supernatant were collected for BCA protein assay determining protein concentration. For Western blot analysis, 25 fish embryos per group were used for protein extraction, whilst, for streptavidin affinity purification, approximately 350 embryos were used for each group. 
bioRxiv preprint doi: https://doi.org/10.1101/2020.11.05.370585; this version posted November 6, 2020. The copyright holder for this preprint (which was not certified by peer review) is the author/funder. All rights reserved. No reuse allowed without permission.

\section{Western blotting}

Western blot analysis was performed largely as described previously Lo et al., 2015. Briefly, zebrafish samples from protein extraction were mixed with NUPAGETM LDS sample buffer (4X) and $10 \mathrm{mM} \mathrm{DTT}$. Protein samples were analysed by Western blotting with following antibodies: mouse anti-Myc (dilution 1:2000), mouse anti-Actin (dilution 1:5000), rabbit anti-Cavin4b (dilution 1:2000), anti-mouse and anti-rabbit HRPconjugated antibodies (dilution 1:5000), streptavidin-HRP (dilution 1:5000). ECL blotting reagent was used to visualise HRP and chemiluminescent signal was detected using the ChemiDoc MP system (BioRad) as per the manufacture's instruction.

\section{Streptavidin beads pulldowns}

Fresh embryo protein extracts (4 mg in $2.5 \mathrm{ml} \mathrm{RIPA}$ buffer) was passed through PD-10 desalting column (GE Healthcare) to remove excess free biotin using the gravity protocol according to manufacturer's instruction. Protein extracts were then mixed with Dynabeads MyOne Streptavidin C1 (Invitrogen) from $200 \mu \mathrm{l}$ bead slurry that were pre-washed with RIPA buffer, and incubated on a rotor wheel at $4{ }^{\circ} \mathrm{C}$ overnight $(16 \mathrm{~h})$. The next day, the beads were separated from the protein extracts on a magnetic rack and transferred to a new $2 \mathrm{ml}$ LoBind tube (Eppendorf). The beads were washed with $1 \mathrm{ml}$ of each following solution: twice with RIPA buffer, once with $2 \%$ SDS in $50 \mathrm{mM}$ Tris- $\mathrm{HCl}$ pH7.5, once with $2 \mathrm{M}$ urea in $10 \mathrm{mM}$ Tris- $\mathrm{HCl} \mathrm{pH8.0} \mathrm{and} \mathrm{twice} \mathrm{again} \mathrm{in} \mathrm{RIPA} \mathrm{buffer} \mathrm{without} \mathrm{cOmplete} \mathrm{Protease} \mathrm{Inhibitor.} \mathrm{Washed} \mathrm{beads}$ were boiled in $60 \mathrm{ul}$ of $2 \mathrm{X}$ Blot LDS sample buffer (4X diluted to $2 \mathrm{X}$ with RIPA buffer) containing $2 \mathrm{mM}$ biotin and $20 \mathrm{mM}$ DTT at $95^{\circ} \mathrm{C}$ for 10 min with $10 \mathrm{~s}$ vortex after first $5 \mathrm{~min}$ boiling. $5 \mathrm{ul}$ of the pulldown samples was used for immunoblots, while the $50 \mathrm{ul}$ of the samples were used for SDS-PAGE with SYPRO Ruby (Invitrogen) or InstantBlue protein gel stain ().

\section{Immunostaining and confocal microscopy}

Fish embryos after in vivo biotin labelling were fixed in $4 \%$ paraformaldehyde (PFA) overnight at $4{ }^{\circ} \mathrm{C}$. After fixation, embryos were permeabilised by proteinase $\mathrm{K}(10 \mathrm{\mu g} / \mathrm{ml}, 10 \mathrm{~min}$ for embryos at $2 \mathrm{dpf}$, or $15 \mathrm{~min}$ for embryos at $3 \mathrm{dpf}$ ), and fixed again with $4 \%$ PFA for 15 min. Embryos were washes with PBS-Tween $20(0.1 \%)$ and blocked in PBS with $0.3 \%$ Triton X-100 and 4\% BSA for $3 \mathrm{~h}$ at room temperature. Staining was performed in blocking buffer with NeutrAvidin-DyLight (1:500 dilution) overnight at $4{ }^{\circ} \mathrm{C}$ followed by 4 washes with PBS $0.3 \%$ Trition X-100. For nuclear staining, embryos were stained with DAPI for $10 \mathrm{~min}$ followed by 3 washes with PBS $0.3 \%$ Trition X-100.

Confocal imaging was performed on Zeiss 710 meta upright confocal microscopes. Zebrafish embryos were mounted in $1 \%$ low melting point agarose in embryos media (Westerfield, 2007) on a standard $8 \mathrm{~cm}$ petri dish. Objectives used were Zeiss water immersion $x 40$ N/A 1.0 (catalogue number 420762). For live embryo imaging, embryos were anaesthetised in $2.5 \mathrm{mM}$ tricaine prior to imaging.

\section{Sample preparation for mass spectrometry}

For in-gel digestion, the streptavidin pulldown samples were separated by SDS-PAGE on a 4-12\% precast gel (Blot ${ }^{\mathrm{TM}}$ Bis-Tris Plus, Invitrogen) and then stained with InstantBlue (Expedeon). The whole lane was excised from the gel and future cut into approximate $3 \times 1 \times 2 \mathrm{~mm}^{3}$ slices $(\mathrm{L} \times \mathrm{W} \times \mathrm{H})$ and each slice were placed into a separate LoBind tubes (Eppendorf) for destaining. The gels were destained by adding $500 \mu \mathrm{l}$ of $100 \mathrm{mM}$ ammonium bicarbonate/acetonitrile $(1: 1, \mathrm{vol} / \mathrm{vol})$ and incubated with occasional vortexing for $30 \mathrm{~min}$. The ammonium bicarbonate/acetonitrile buffer was removed, and the gel pieces dried for $15 \mathrm{~min}$ by the addition of $200 \mu \mathrm{l}$ of acetonitrile. The acetonitrile was removed and another $200 \mu \mathrm{l}$ aliquot was added and left for 15-30 min. The acetonitrile was removed in preparation for trypsin digestion. After destain, the gel pieces were covered with $200 \mu \mathrm{l}$ of $20 \mathrm{ng} / \mu \mathrm{l}$ of sequence grade trypsin/Lys-C (Promega) in $50 \mathrm{mM}$ ammonium bicarbonate $\mathrm{pH} 8$ buffer. The gel pieces were left for $1 \mathrm{~h}$ and if required a further $100 \mu \mathrm{l}$ of trypsin/Lys-C solution was added to cover the gel pieces. The samples were placed in an incubator at $37^{\circ} \mathrm{C}$ overnight. The trypsin solution was transferred from each sample and placed in a clean Eppendorf tube. $200 \mu \mathrm{l}$ of $5 \%$ formic acid/acetonitrile $(3: 1, \mathrm{vol} / \mathrm{vol})$ was added to each tube and incubated for $15 \mathrm{~min}$ at room temperature in a shaker. The supernatant was placed into the pre-cleaned Eppendorf tubes, together with the trypsin solution for each sample and dried down in a vacuum centrifuge.

For HPLC/MS MS/MS analysis, $12 \mu \mathrm{l}$ of $1.0 \%$ (vol/vol) trifluoroacetic acid in water was added to the tube, which was vortexed and incubated for $2 \mathrm{~min}$ in the sonication bath and then centrifuged for $1 \mathrm{~min}$ at 6,700 xg $(10,000 \mathrm{rpm})$ and finally, transferred to an autosampler vial for analysis.

\section{Lipid chromatography and mass spectrometry}

The tryptic peptide extracts were analysed by nanoHPLC/MS MS/MS on an Eksigent ekspert ${ }^{\mathrm{TM}}$ nanoLC 400 system (SCIEX) coupled to a Triple TOF 6600 mass spectrometer (SCIEX) equipped with PicoView nanoflow (New Objective) ion source. $5 \mu \mathrm{l}$ of each extract was injected onto a $5 \mathrm{~mm} \times 300 \mu \mathrm{m}$, C18 $3 \mu \mathrm{m}$ trap column (SGE, Australia) for $5 \mathrm{~min}$ at $10 \mu \mathrm{L} / \mathrm{min}$. The trapped tryptic peptide extracts were then washed onto the analytical $75 \mu \mathrm{m} \times 150 \mathrm{~mm}$ ChromXP C18 CL $3 \mu \mathrm{m}$ column (SCIEX) at $400 \mathrm{nl} / \mathrm{min}$ and a column temperature of $45^{\circ} \mathrm{C}$. Linear gradients of 2-40\% solvent B over $60 \mathrm{~min}$ at $400 \mathrm{nl} / \mathrm{min}$ flowrate, followed by a steeper gradient from $40 \%$ to $90 \%$ solvent B in $5 \mathrm{~min}$, then $90 \%$ solvent $B$ for $5 \mathrm{~min}$, were used for peptide elution. The gradient was then returned to $2 \%$ solvent $B$ for equilibration prior to the next sample injection. Solvent A consisted of $0.1 \%$ formic acid in water and solvent B contained $0.1 \%$ formic acid in acetonitrile. The ionspray voltage was set to $2600 \mathrm{~V}$, declustering potential (DP) 80V, curtain gas flow 30, nebuliser gas 1 (GS1) 30, interface heater at 150․ The mass spectrometer acquired $50 \mathrm{~ms}$ full scan TOF-MS data followed by up to $30100 \mathrm{~ms}$ full scan product ion data, with a rolling collision energy, in an Information Dependant Acquisition, IDA, mode for protein identification and peptide library production. Full scan TOFMS data was acquired over the mass range 350-1800 and for product ion ms/ms 100-1500. lons observed in the TOF-MS scan exceeding a threshold of 200 counts and a charge state of +2 to +5 were set to trigger the acquisition of product ion, $\mathrm{ms} / \mathrm{ms}$ spectra of the resultant 30 most intense ions.

\section{MS Data analysis and GO annotation}

The data was acquired and processed using Analyst TF 1.7 software (SCIEX). Protein identification was carried out using ProteinPilot ${ }^{\mathrm{TM}}$ software v5.0 (SCIEX) with Paragon ${ }^{\mathrm{TM}}$ database search algorithm. MS/MS spectra were searched against all zebrafish proteins annotated at UniProt database. The peptide evidence from the search was assembled by Pro Group ${ }^{\mathrm{TM}}$ Algorithm to generate a list of protein identification with Protein Score (ProtScore). The ProtScore was calculated based on the number and the confidence of identified peptides. The peptide identifications could only contribute to the Unused ProtScore of a protein to the extent that their spectra have not already been used to justify an already assigned more confident protein. Proteins were only reported as detected if they had sufficient Unused ProtScore. 
bioRxiv preprint doi: https://doi.org/10.1101/2020.11.05.370585; this version posted November 6, 2020. The copyright holder for this preprint (which was not certified by peer review) is the author/funder. All rights reserved. No reuse allowed without permission.

The ProScore of each protein were firstly normalised to the ProtScore of an endogenous biotinylated protein, propionyl-CoA carboxiylase subunit alpha, detected within the group. The enrichment score (ES) was calculated by dividing ProtScore of each protein in cavin group by the combined ProtScore of that protein in both cavin and control groups.

$$
E S=\frac{\text { ProtScore }_{(\text {cavin })}}{\text { ProtScore }_{(\text {cavin })}+\text { ProtScore }_{(\text {ctrl })}}
$$

Therefore, a protein that is only identified in cavin group will have an enrichment score of 1 , while endogenous biotinylated proteins and non-specific binder would likely have an enrichment score around 0.5 .

The GO annotation for our identified proteins was carried out using DAVID 6.8 (Huang da et al., 2009b, a). For zebrafish proteins without annotation information, manually annotation was performed by searching their human or mouse homologs.

\section{Acknowledgements}

We would like to thank Dr. Anne Lagendijk and Dr. Jean Giacomotto for $T g(k d r l: E G F P)$ and $T g$ (MotoN:EGFP) fish lines, respectively. Confocal microscopy was performed at the Australian Cancer Research Foundation (ACRF)/Institute for Molecular Bioscience (IMB) Dynamic Imaging Facility for Cancer Biology with funding from the ACRF. MS spectrometry was performed at the IMB Mass Spectrometry Facility, the University of Queensland. This work was supported by fellowship and grants from the National Health and Medical Research Council of Australia (to R.G. P., grant numbers 569542 and 1045092; to R.G.P., grant number APP1044041; and to T.E. H. and R.G.P., grant number APP1099251), the Australian Research Council (to T.E.H. and P.G.P., grant number DP200102559) as well as by the Australian Research Council Centre of Excellence in Convergent Bio-Nano Science and Technology (to R.G.P., grant number CE140100036).

\section{Competing interests}

No competing interests declared

\section{References}

Agrawal, P.B., Pierson, C.R., Joshi, M., Liu, X., Ravenscroft, G., Moghadaszadeh, B., Talabere, T., Viola, M., Swanson, L.C., Haliloglu, G., Talim, B., Yau, K.S., Allcock, R.J.N., Laing, N.G., Perrella, M.A., Beggs, A.H. (2014). SPEG interacts with myotubularin, and its deficiency causes centronuclear myopathy with dilated cardiomyopathy. Am J Hum Genet 95, 218-226.

Ahmed, R., Spikings, E., Zhou, S., Thompsett, A., and Zhang, T. (2014). Pre-hybridisation: an efficient way of suppressing endogenous biotin-binding activity inherent to biotin-streptavidin detection system. J Immunol Methods 406, 143-147.

Ariotti, N., Hall, T.E., Rae, J., Ferguson, C., McMahon, K.A., Martel, N., Webb, R.E., Webb, R.I., Teasdale, R.D., and Parton, R.G. (2015). Modular Detection of GFP-Labeled Proteins for Rapid Screening by Electron Microscopy in Cells and Organisms. Dev Cell 35, $513-525$.

Ariotti, N., Rae, J., Giles, N., Martel, N., Sierecki, E., Gambin, Y., Hall, T.E., and Parton, R.G. (2018). Ultrastructural localisation of protein interactions using conditionally stable nanobodies. PLoS Biol 16, e2005473.

Bastiani, M., Liu, L., Hill, M.M., Jedrychowski, M.P., Nixon, S.J., Lo, H.P., Abankwa, D., Luetterforst, R., Fernandez-Rojo, M., Breen, M.R., Gygi, S.P., Vinten, J., Walser, P.J., North, K.N., Hancock, J.F., Pilch, P.F., Parton, R.G. (2009). MURC/Cavin-4 and cavin family members form tissue-specific caveolar complexes. J Cell Biol 185, 1259-1273.

Beis, D., Bartman, T., Jin, S.W., Scott, I.C., D'Amico, L.A., Ober, E.A., Verkade, H., Frantsve, J., Field, H.A., Wehman, A., Baier, H., Tallafuss, A., Bally-Cuif, L., Chen, J.N., Stainier, D.Y.R., Jungblut, B. (2005). Genetic and cellular analyses of zebrafish atrioventricular cushion and valve development. Development 132, 4193-4204.

Branon, T.C., Bosch, J.A., Sanchez, A.D., Udeshi, N.D., Svinkina, T., Carr, S.A., Feldman, J.L., Perrimon, N., and Ting, A.Y. (2018). Efficient proximity labeling in living cells and organisms with TurbolD. Nat Biotechnol 36, 880-887.

Casadei, R., Pelleri, M.C., Vitale, L., Facchin, F., Lenzi, L., Canaider, S., Strippoli, P., and Frabetti, F. (2011). Identification of housekeeping genes suitable for gene expression analysis in the zebrafish. Gene Expr Patterns 11, 271-276.

Cipolletta, E., Monaco, S., Maione, A.S., Vitiello, L., Campiglia, P., Pastore, L., Franchini, C., Novellino, E., Limongelli, V., Bayer, K.U., Means, A.R., Rossi G., Trimarco, B., laccarino, G., Illario, M. (2010). Calmodulin-dependent kinase II mediates vascular smooth muscle cell proliferation and is potentiated by extracellular signal regulated kinase. Endocrinology 151, 2747-2759.

Cipolletta, E., Rusciano, M.R., Maione, A.S., Santulli, G., Sorriento, D., Del Giudice, C., Ciccarelli, M., Franco, A., Crola, C., Campiglia, P., Sala, M., Gomez-Monterrey, I., De Luca, N., Trimarco, B., laccarino, G., Illario, M. (2015). Targeting the CaMKII/ERK Interaction in the Heart Prevents Cardiac Hypertrophy. PLoS One 10, e0130477.

Deconinck, N., and Dan, B. (2007). Pathophysiology of duchenne muscular dystrophy: current hypotheses. Pediatr Neurol 36, 1-7.

Ding, S.Y., Liu, L., and Pilch, P.F. (2017). Muscular dystrophy in PTFR/cavin-1 null mice. JCI Insight 2, e91023. 
bioRxiv preprint doi: https://doi.org/10.1101/2020.11.05.370585; this version posted November 6, 2020. The copyright holder for this preprint (which was not certified by peer review) is the author/funder. All rights reserved. No reuse allowed without permission.

Donnelly, M.L.L., Luke, G., Mehrotra, A., Li, X., Hughes, L.E., Gani, D., and Ryan, M.D. (2001). Analysis of the aphthovirus 2A/2B polyprotein 'cleavage' mechanism indicates not a proteolytic reaction, but a novel translational effect: a putative ribosomal 'skip'. J Gen Virol 82, 1013-1025.

Doyle, D.D., Goings, G., Upshaw-Earley, J., Ambler, S.K., Mondul, A., Palfrey, H.C., and Page, E. (2000). Dystrophin associates with caveolae of rat cardiac myocytes: relationship to dystroglycan. Circ Res 87, 480-488.

Gingras, A.C., Abe, K.T., and Raught, B. (2019). Getting to know the neighborhood: using proximity-dependent biotinylation to characterize protein complexes and map organelles. Curr Opin Chem Biol 48, 44-54.

Hamers-Casterman, C., Atarhouch, T., Muyldermans, S., Robinson, G., Hamers, C., Songa, E.B., Bendahman, N., and Hamers, R. (1993). Naturally occurring antibodies devoid of light chains. Nature 363, 446-448.

Hayashi, Y.K., Matsuda, C., Ogawa, M., Goto, K., Tominaga, K., Mitsuhashi, S., Park, Y.E., Nonaka, I., Hino-Fukuyo, N., Haginoya, K., Sugano, H., Nishino, I. (2009). Human PTRF mutations cause secondary deficiency of caveolins resulting in muscular dystrophy with generalized lipodystrophy. J Clin Invest 119, 2623-2633.

Higashijima, S., Okamoto, H., Ueno, N., Hotta, Y., and Eguchi, G. (1997). High-frequency generation of transgenic zebrafish which reliably express GFP in whole muscles or the whole body by using promoters of zebrafish origin. Dev Biol 192, 289-299.

Hill, M.M., Bastiani, M., Luetterforst, R., Kirkham, M., Kirkham, A., Nixon, S.J., Walser, P., Abankwa, D., Oorschot, V.M., Martin, S., Hancock, J.F., Parton, R.G. (2008). PTRF-Cavin, a conserved cytoplasmic protein required for caveola formation and function. Cell 132, 113-124.

Hnia, K., Ramspacher, C., Vermot, J., and Laporte, J. (2015). Desmin in muscle and associated diseases: beyond the structural function. Cell Tissue Res 360, 591-608.

Housley, M.P., Njaine, B., Ricciardi, F., Stone, O.A., Holper, S., Kruger, M., Kostin, S., and Stainier, D.Y. (2016). Cavin4b/Murcb Is Required for Skeletal Muscle Development and Function in Zebrafish. PLoS Genet 12, e1006099.

Housley, M.P., Reischauer, S., Dieu, M., Raes, M., Stainier, D.Y., and Vanhollebeke, B. (2014). Translational profiling through biotinylation of tagged ribosomes in zebrafish. Development 141, 3988-3993.

Huang da, W., Sherman, B.T., and Lempicki, R.A. (2009a). Bioinformatics enrichment tools: paths toward the comprehensive functional analysis of large gene lists. Nucleic Acids Res 37, 1-13.

Huang da, W., Sherman, B.T., and Lempicki, R.A. (2009b). Systematic and integrative analysis of large gene lists using DAVID bioinformatics resources. Nat Protoc 4, 44-57.

Illario, M., Cavallo, A.L., Bayer, K.U., Di Matola, T., Fenzi, G., Rossi, G., and Vitale, M. (2003). Calcium/calmodulin-dependent protein kinase II binds to Raf-1 and modulates integrin-stimulated ERK activation. J Biol Chem 278, 45101-45108.

Kawakami, K. (2004). Transgenesis and gene trap methods in zebrafish by using the Tol2 transposable element. Methods Cell Biol 77, 201222.

Kim, D.I., Jensen, S.C., Noble, K.A., Kc, B., Roux, K.H., Motamedchaboki, K., and Roux, K.J. (2016). An improved smaller biotin ligase for BiolD proximity labeling. Mol Biol Cell 27, 1188-1196.

Kim, J.H., Lee, S.R., Li, L.H., Park, H.J., Park, J.H., Lee, K.Y., Kim, M.K., Shin, B.A., and Choi, S.Y. (2011). High cleavage efficiency of a 2A peptide derived from porcine teschovirus-1 in human cell lines, zebrafish and mice. PLoS One 6, e18556.

Kwan, K.M., Fujimoto, E., Grabher, C., Mangum, B.D., Hardy, M.E., Campbell, D.S., Parant, J.M., Yost, H.J., Kanki, J.P., and Chien, C.B. (2007). The Tol2kit: a multisite gateway-based construction kit for Tol2 transposon transgenesis constructs. Dev Dyn 236, 3088-3099.

Liu, L., and Pilch, P.F. (2016). PTRF/Cavin-1 promotes efficient ribosomal RNA transcription in response to metabolic challenges. eLife 5, e17508.

Lo, H.P., Nixon, S.J., Hall, T.E., Cowling, B.S., Ferguson, C., Morgan, G.P., Schieber, N.L., Fernandez-Rojo, M.A., Bastiani, M., Floetenmeyer, M., Martel, N., Laporte, J., Pilch, P.F., Parton, R.G. (2015). The caveolin-cavin system plays a conserved and critical role in mechanoprotection of skeletal muscle. J Cell Biol 210, 833-849.

Mair, A., Xu, S.L., Branon, T.C., Ting, A.Y., and Bergmann, D.C. (2019). Proximity labeling of protein complexes and cell-type-specific organellar proteomes in Arabidopsis enabled by TurbolD. eLife 8, e47864.

McMahon, K.A., Wu, Y., Gambin, Y., Sierecki, E., Tillu, V.A., Hall, T., Martel, N., Okano, S., Moradi, S.V., Ruelcke, J.E., Ferguson, C., Yep, A.S., Alexandrov, K., Hill, M.M., Parton, R.G. (2019). Identification of intracellular cavin target proteins reveals cavin-PP1alpha interactions regulate apoptosis. Nat Commun 10, 3279.

Nicot, A.S., Toussaint, A., Tosch, V., Kretz, C., Wallgren-Pettersson, C., Iwarsson, E., Kingston, H., Garnier, J.M., Biancalana, V., Oldfors, A., Mandel, J.L., Laporte, J. (2007). Mutations in amphiphysin 2 (BIN1) disrupt interaction with dynamin 2 and cause autosomal recessive centronuclear myopathy. Nat Genet 39, 1134-1139.

Nusslein-Volhard, C., and Dahm, R. (2002). Zebrafish: A Practical Approach, First edn (Oxford University Press).

Ogata, T., Naito, D., Nakanishi, N., Hayashi, Y.K., Taniguchi, T., Miyagawa, K., Hamaoka, T., Maruyama, N., Matoba, S., Ikeda, K., Yamada, H., Oh, H., Ueyama, T. (2014). Proc Natl Acad Sci U S A 111, 3811-3816.

Parton, R.G., Tillu, V.A., and Collins, B.M. (2018). Caveolae. Curr Biol 28, R402-R405.

Punnamoottil, B., Rinkwitz, S., Giacomotto, J., Svahn, A.J., and Becker, T.S. (2015). Motor neuron-expressed microRNAs 218 and their enhancers are nested within introns of Slit2/3 genes. Genesis 53, 321-328.

Rajab, A., Straub, V., McCann, L.J., Seelow, D., Varon, R., Barresi, R., Schulze, A., Lucke, B., Lutzkendorf, S., Karbasiyan, M., Bachmann, S., Spuler, S., Schuelke, M. (2010). Fatal Cardiac Arrhythmia and Long-QT Syndrome in a New Form of Congenital Generalized Lipodystrophy with Muscle Rippling (CGL4) Due to PTRF-CAVIN Mutations. PLoS Genet 6.

Ramanathan, M., Majzoub, K., Rao, D.S., Neela, P.H., Zarnegar, B.J., Mondal, S., Roth, J.G., Gai, H., Kovalski, J.R., Siprashvili, Z., Palmer, T.D., Carette, J.E., Khavari, P.A. (2018). RNA-protein interaction detection in living cells. Nat Methods 15, 207-212. 
bioRxiv preprint doi: https://doi.org/10.1101/2020.11.05.370585; this version posted November 6, 2020. The copyright holder for this preprint (which was not certified by peer review) is the author/funder. All rights reserved. No reuse allowed without permission.

Rodriguez, G., Ueyama, T., Ogata, T., Czernuszewicz, G., Tan, Y., Dorn, G.W., 2nd, Bogaev, R., Amano, K., Oh, H., Matsubara, H., Willerson, J.T., Marian, A.J. (2011). Molecular genetic and functional characterization implicate muscle-restricted coiled-coil gene (MURC) as a causal gene for familial dilated cardiomyopathy. Circ Cardiovasc Genet 4, 349-358.

Rose, A.J., Kiens, B., and Richter, E.A. (2006). Ca2+-calmodulin-dependent protein kinase expression and signalling in skeletal muscle during exercise. J Physiol 574, 889-903.

Rothbauer, U., Zolghadr, K., Muyldermans, S., Schepers, A., Cardoso, M.C., and Leonhardt, H. (2008). A versatile nanotrap for biochemical and functional studies with fluorescent fusion proteins. Mol Cell Proteomics 7, 282-289.

Roux, K.J., Kim, D.I., Raida, M., and Burke, B. (2012). A promiscuous biotin ligase fusion protein identifies proximal and interacting proteins in mammalian cells. J Cell Biol 196, 801-810.

Seemann, E., Sun, M., Krueger, S., Troger, J., Hou, W., Haag, N., Schuler, S., Westermann, M., Huebner, C.A., Romeike, B., Kessels, M.M., Qualmann, B. (2017). Deciphering caveolar functions by syndapin III KO-mediated impairment of caveolar invagination. eLife 6, e29854.

Selcen, D., and Engel, A.G. (2005). Mutations in ZASP define a novel form of muscular dystrophy in humans. Ann Neurol 57, 269-276.

Shaner, N.C., Lambert, G.G., Chammas, A., Ni, Y., Cranfill, P.J., Baird, M.A., Sell, B.R., Allen, J.R., Day, R.N., Israelsson, M., Davidson, M.W., Wang, J. (2013). A bright monomeric green fluorescent protein derived from Branchiostoma lanceolatum. Nat Methods 10, 407-409.

Shcherbo, D., Murphy, C.S., Ermakova, G.V., Solovieva, E.A., Chepurnykh, T.V., Shcheglov, A.S., Verkhusha, V.V., Pletnev, V.Z., Hazelwood, K.L., Roche, P.M., Lukyanov, S., Zaraisky, A.G., Davidson, M.W., Chudakov, D.M. (2009). Far-red fluorescent tags for protein imaging in living tissues. Biochem J 418, 567-574.

Song, K.S., Scherer, P.E., Tang, Z.L., Okamoto, T., Li, S.W., Chafel, M., Chu, C., Kohtz, D.S., and Lisanti, M.P. (1996). Expression of caveolin-3 in skeletal, cardiac, and smooth muscle cells - Caveolin-3 is a component of the sarcolemma and co-fractionates with dystrophin and dystrophin-associated glycoproteins. J Biol Chem 271, 15160-15165.

Tang, J.C., Drokhlyansky, E., Etemad, B., Rudolph, S., Guo, B., Wang, S., Ellis, E.G., Li, J.Z., and Cepko, C.L. (2016). Detection and manipulation of live antigen-expressing cells using conditionally stable nanobodies. eLife 5, e15312.

Tang, J.C., Rudolph, S., Dhande, O.S., Abraira, V.E., Choi, S., Lapan, S.W., Drew, I.R., Drokhlyansky, E., Huberman, A.D., Regehr, W.G., Cepko, C.L. (2015). Cell type-specific manipulation with GFP-dependent Cre recombinase. Nat Neurosci 18, 1334-1341.

Varnaite, R., and MacNeill, S.A. (2016). Meet the neighbors: Mapping local protein interactomes by proximity-dependent labeling with BiolD. Proteomics 16, 2503-2518.

Westerfield, M. (2007). The Zebrafish Book : A Guide for the Laboratory Use of Zebrafish, Fifth edn (University of Oregon).

Zhang, Y., Song, G., Lal, N.K., Nagalakshmi, U., Li, Y., Zheng, W., Huang, P.J., Branon, T.C., Ting, A.Y., Walley, J.W., Dinesh-Kumar, S.P. (2019). TurbolD-based proximity labeling reveals that UBR7 is a regulator of N NLR immune receptor-mediated immunity. Nat Commun 10, 3252. 
bioRxiv preprint doi: https://doi.org/10.1101/2020.11.05.370585; this version posted November 6, 2020. The copyright holder for this preprint (which was not certified by peer review) is the author/funder. All rights reserved. No reuse allowed without permission.

\section{Supplementary Figures}

A

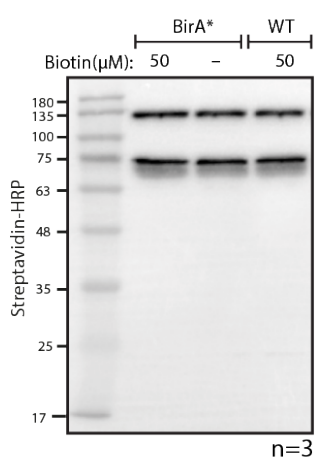

D

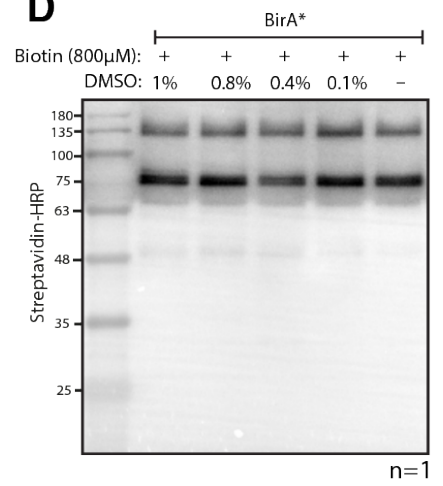

B

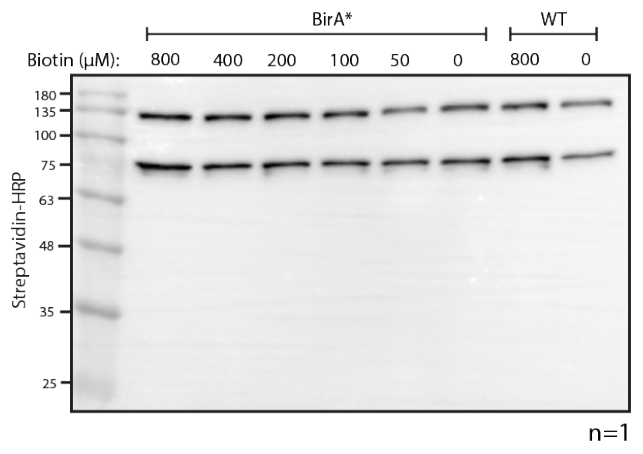

E

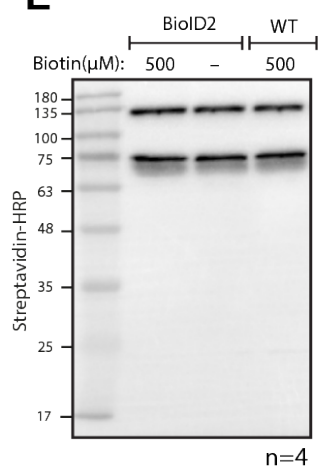

C



$\mathbf{F}$



Temp $\left({ }^{\circ} \mathrm{C}\right): \quad 32.5 \quad 28.0 \quad 32.5 \quad 32.5$

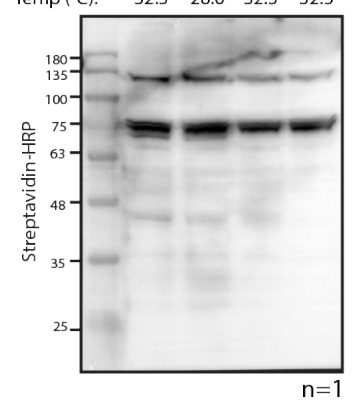

Figure S1 Testing BiolD and BiolD2 in transgenic zebrafish. (A) Streptavidin-HRP blot showing biotinylated proteins in BiolD (BirA*) transgenic zebrafish embryos. Zebrafish embryos were incubated with $50 \mu \mathrm{M}$ biotin for $18 \mathrm{~h}$ prior to protein extraction and Western blotting. (B, $\boldsymbol{C}$ and D) Streptavidin-HRP blots showing biotinylated proteins in zebrafish embryos with (B) increased biotin concentration, (C) increased biotin incubation time and (D) addition of DMSO. (E and F) Streptavidin-HRP blots showing biotinylated proteins in BiolD2 transgenic zebrafish embryos under $(E)$ standard incubation temperature $(28 \stackrel{\circ}{\circ})$ and $(\boldsymbol{F})$ elevated temperature $\left(32.5{ }^{\circ} \mathrm{C}\right)$ during biotin incubation. Each sample is a pool of 30 embryos at $3 \mathrm{dpf}$. The two prominent protein bands present in all samples were endogenous biotinylated proteins. 
bioRxiv preprint doi: https://doi.org/10.1101/2020.11.05.370585; this version posted November 6, 2020. The copyright holder for this preprint (which was not certified by peer review) is the author/funder. All rights reserved. No reuse allowed without permission.
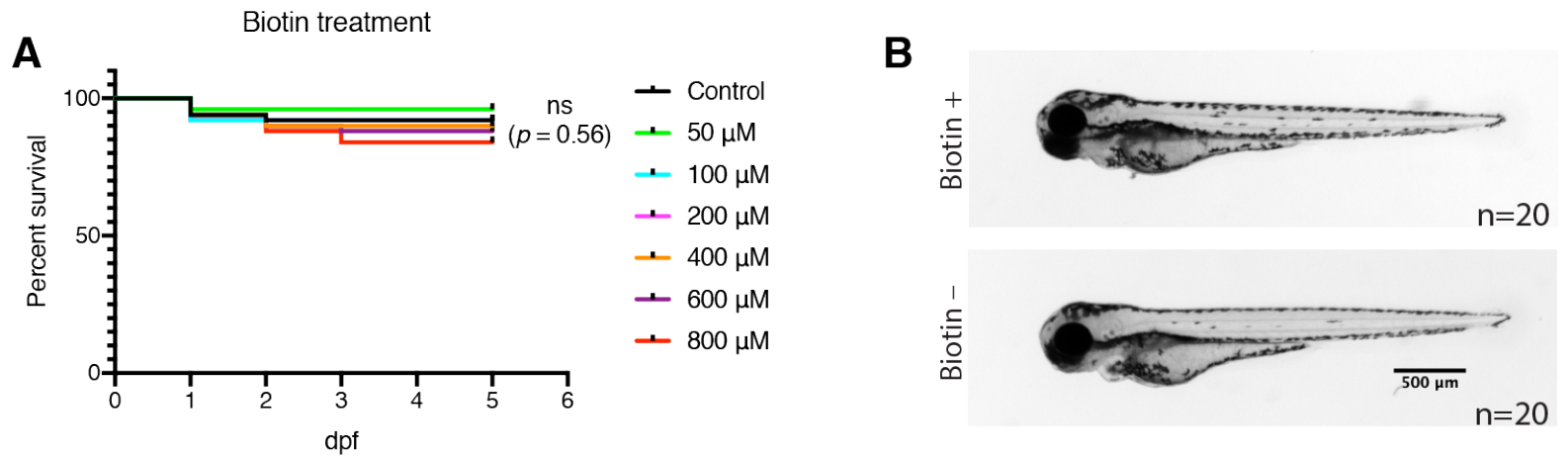

Figure S2 Determining biotin toxicity and tolerance in zebrafish embryos. (A) The fish embryos were incubated with biotin solution at indicated concentration from 1 to $5 \mathrm{dpf}$. Fifty WT embryos were used for each treatment group. Dead embryos were removed and counted each day. The statistics were performed using Log-rank (Mantel-Cox) test; ns denotes not significant. (B) representative images showing the fish embryo morphology at $3 \mathrm{dpf}$ with or without biotin $(600 \mu \mathrm{M})$ incubation.

A

TurbolD-dGBP level: $\quad++++$

Cavin1a-clover: +

Biotin: +
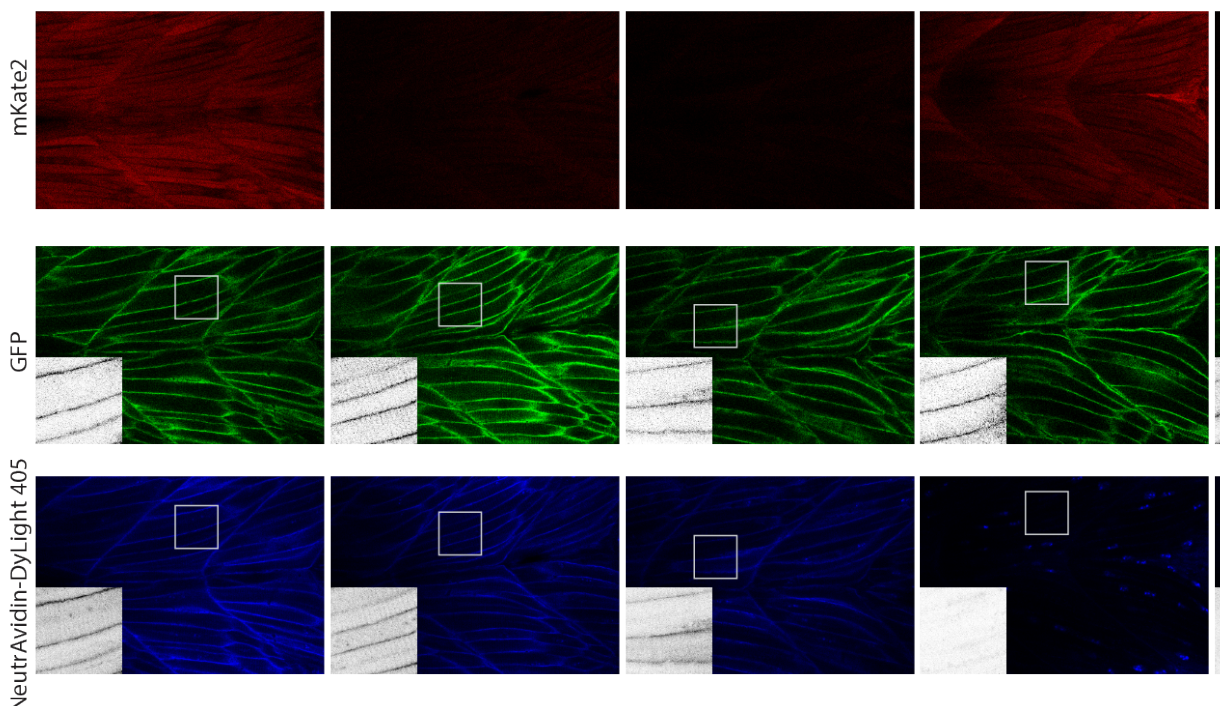
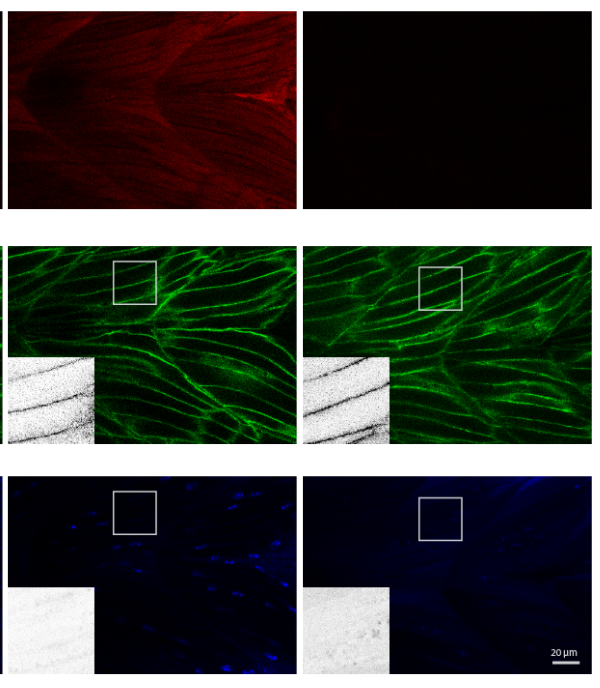

Figure S3 The specificity of TurbolD-dGBP biotin labelling is independent of its expression level in zebrafish embryos. (A) Representative images showing biotinylated proteins in zebrafish embryos from outcrossing Cavin1a-Clover with different TurbolD-dGBP lines. The number of " + " denotes the expression level of TurbolD as reflected by mKate2 fluorescent reporter. The scale bar represents $20 \mu \mathrm{m}$. 
bioRxiv preprint doi: https://doi.org/10.1101/2020.11.05.370585; this version posted November 6, 2020. The copyright holder for this preprint (which was not certified by peer review) is the author/funder. All rights reserved. No reuse allowed without permission.
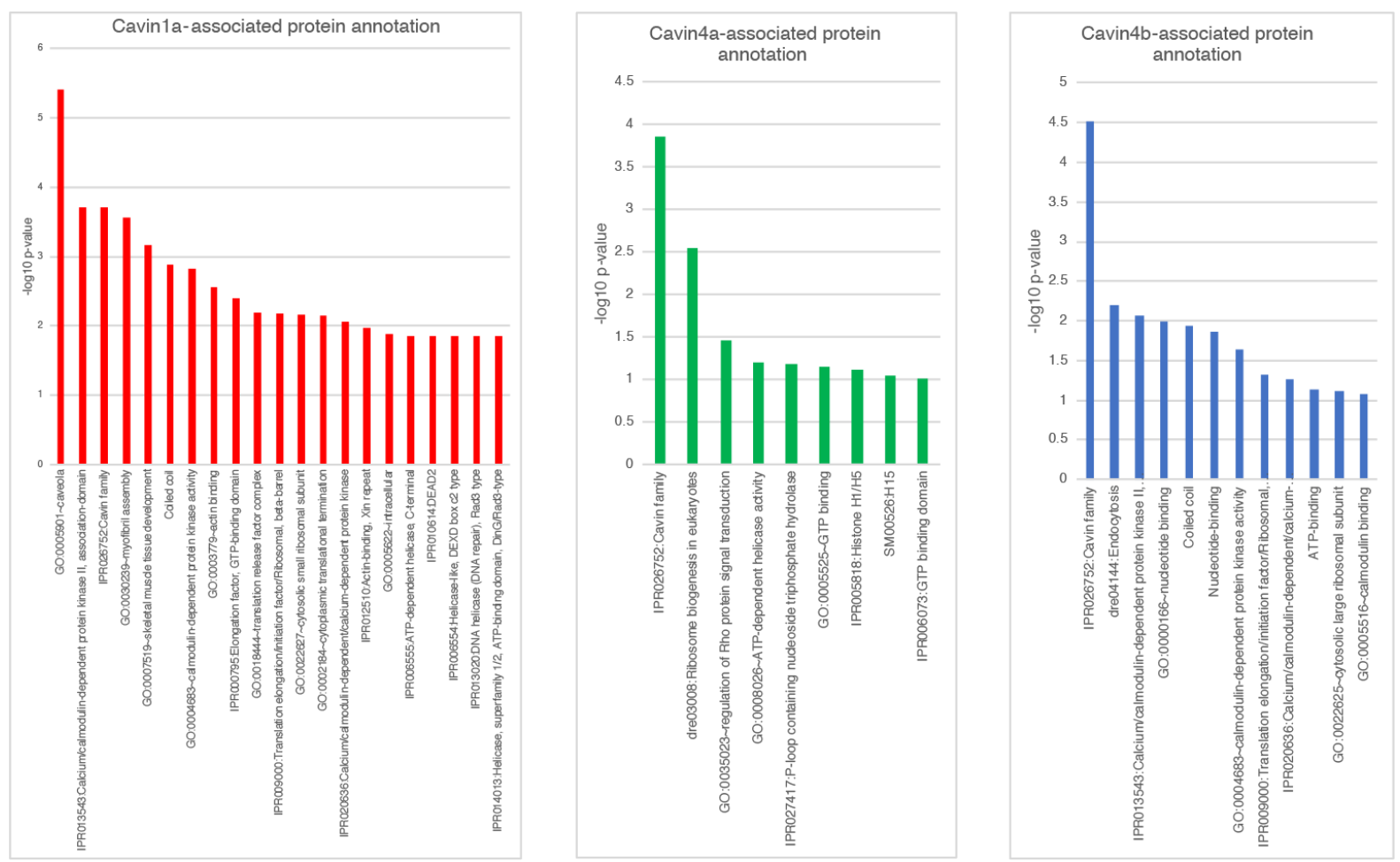

Figure S4 Gene ortholog annotation of cavin proteomes. The annotation was performed on DAVID Bioinformatics Resources 6.8. For proteins without existing information, their human or mouse orthologs were used. Y-axis shows -log10 adjust p-values from Benjamini-Hochberg procedure calculated by DAVID Bioinformatics Resources 6.8. Only proteins pass the cut-off (ES>0.9) were analysed. 